\title{
Practices and Problems of Exercising Distributive Leadership in Public Secondary Schools of East Hararghe Zone, Oromia Regional State
} Bayisa Ishetu $^{{ }^{*}}$, Mulugeta Geleta ${ }^{2}$, Guyasa Desalegn ${ }^{3}$

*Corresponding author: Bayisa Ishetu

\section{Abstract}

The main purpose of this study was to examine Practices and problems of exercising Distributive Leadership in Public Secondary Schools of East Hararghe Zone, Oromia Regional State. To conduct this study, explanatory sequnatial mxed method design was employed. A total of 155 respondents (120 teachers, 6 principals, 6 vice principals, 12 unit leaders, 5 supervisors and 6 PTSA heads) was included in the study. The principals, vice-principals, unit leaders, supervisors and PTSA heads were selected using availability sampling while the teachers respondents were selected using stratified random sampling technique. The data were gathered through questionnaire and interview. Data gathered through questionnaire were analyzed using percentage, frequency, mean, weighted mean, standard deviation and stepwise regression. Data obtained through interview and open-ended questionnaire were analyzed qualitatively. Findings from the data analysis revealed that teacher's participation, roles and involvement in decision-making in distributive leadership practices was low. The study showed that, respondents were disagreed regarding the issue school leaders and teachers are familiar with their colleagues for taking leadership role and have concepts about distributive leadership under study area. Unwillingness to work in a team, lack of smooth communication, lack of trust among school stakeholders and reluctance of teachers to delegate were some of the major problems that deterred distributive leadership practices under study area. On the basis of these major findings and conclusion, the following recommendations were made. ZEO, in collaboration with WEO, should provide short and long term training regarding leadership practices to schools leaders in the form of workshops and seminars. School leaders should work more on empower, capacitate and create opportunity for all teachers, so that teachers will be fully involved in leadership practices.

Keywords: Problems, distributive leadership, secondary schools, practices.

Copyright @ 2020: This is an open-access article distributed under the terms of the Creative Commons Attribution license which permits unrestricted use, distribution, and reproduction in any medium for non-commercial use (NonCommercial, or CC-BY-NC) provided the original author and source are credited.

\section{INTRODUCTION}

This chapter deals with the background of the study, statement of the problem, basic research questions, objectives of the study, significance of the study, delimitation of the study, limitation of the study and definition of key terms.

\section{Background of the Study}

Leadership is a complex phenomenon that exists in any organization where the need of inspiring and influencing members of the given organization. Gronn [1] states leadership as a process whereby an individual influences a group of individuals to achieve a common goal in the organization. Secondary schools adapt and apply different types of leadership approach that fits the existing context to achieve their own mission and goals. However the old way of leading people in this very flux and turbulent world become the risky job for the secondary schools leaders. Besides, very swift global trends and local demands of education make the size and complexity of secondary schools too big to lead.

The concept and understanding of distributive leadership vary widely. There are competing and sometimes conflicting interpretations of what distributed leadership means [2]. The diverse concepts mean that distributive leadership is frequently used to describe any form of devolved, shared or distributed leadership practice in schools [3]. Theoretically, the perspective of distributive leadership acknowledges that multiple individuals are involved in the leading and managing of schools and shifts the focus from formal leaders to a web of leaders in schools [4-6].

Deem [7] states that the concept of distributive leadership has been recommended as a response to new 
challenges posed towards educational institutions based on the understanding that mere hierarchical leadership practices are not well suited to global complexity. Recent distributive leadership approach can be said to fully change even ignore the traditional leadership and leader definitions since leadership in distributive leadership approach has a more complex structure than leadership behaviors $[8,9]$.

According to Spillane [5] distributive leadership is a system of practices compromise a collection of interacting components of leaders, followers and situation. These interacting components should be understood together because the system is more than the sum of the component parts. Besides, distributive leadership goes beyond acknowledging that multiple individuals are involved in leadership practice and exploring the interactions between individuals and investigating the situation in which leadership is enacted. A distributed perspective on leadership is not a prescription for leadership but instead a lens or tool that we can use to examines leadership.

Distributive leadership has become a popular representation of leadership which has encouraged a shift in focus from the attributes and behaviors of individual leaders as promoted within traditional trait, behavioral, situational, and transformational theories of leadership to a more systemic perspective, whereby leadership's conceived as a collective social process emerging through the interactions of multiple actors [10].

From this point of view, Bennett, Wise, Woods, and Harvey [11], argued that:

Distributive leadership is not something done by an individual to others, or a set of individual actions through which people contribute to a group or organization; it is a group of activity what works through and within relationship, rather than individual action.

Thus, in the researcher view, distributive leadership is a result of reflecting the cognizance organizational management regarding the view that leadership roles and positions should be shared. That is to say, distributive leadership addresses the entirety of human resources in organizations, especially the academic staff in educational organizations as leaders rather than relied on individual leaders because a shared vision can be attained more efficiently through shared responsibility.

Successful leaders have to work inside and outside the boundaries of their school context. As there are ambiguities about the activities which may actually be considered leadership, it is difficult to sketch the boundaries of a leaders work [12]. Duignan [13] stated, many educational leaders leave themselves, isolated and alone, taking primary responsibility for the leadership of their school which constitutes a very narrow view of leadership and ignores the leadership talents of teachers, students and other community stakeholders. But an educational institution in general and secondary schools in particular are expected to create knowledge, culture of sharing of energy and commitment to respond students' needs, and societal expectations. These problems coupled with their unique features, such as academic freedom; collegial relationship; specialized and qualified academic staff and its relative open boundary to stimulate education policy makers and leaders to look in to distributive leadership approach to disperse and share leadership among the various members.

Middlehurst [14] states leadership should be distributed across the institution. Despite this, the actual processes and practices by which leadership is distributed and the implications for leadership practice and development in the secondary schools have received relatively little attention. The researcher goal in this study is to examine the practices and challenges of distributive leadership in public secondary schools of East Hararghe Zone.

\section{Statement of the Problem}

In educational organizations, effective leadership provides higher quality of work, more efficient goods and services and it brings about higher level of satisfaction to both service employees and external service recipients. Historically, the conceptions of leadership have passed different phases that extend from the classical notion of heroic leaders to the new leadership approach called distributive leadership [15]. Recently, leadership approach that best fit to the school system has emerged with the concept of distributive leadership as opposed to traditional leadership approach [16].

Secondary schools have impact and are impacted by the supra environment. In order to respond the changing environment, they are expected to involve actively in teaching-learning and creating a culture of the schools that provides coherence, to respond student's needs and exercising leadership practices more than ever. On time and proportional response to the ever changing environment requires new way of leadership approach that encompasses member of the academic staff in decision making in various degree and size. However, despite these continuous and progressive changes of the global aspects, the leadership style of most secondary schools are traditional top-down approach where a decision making power significantly in the hand of top leaders. Harris [17] points out that ignoring the major structural, cultural, and micro political challenges operating in schools makes distributive forms of leadership difficult to implement. Hence, applying leadership style that fit and outdone the unsympathetic and turbulent milieu is not a matter of option, rather it is an issue of survival. 
Spillane [18] state that, the studies on distributed forms of leadership is still at its early stages and the accessible empirical evidence about it is not abundant. However, the features and application of distributive leadership in secondary schools have not been adequately explored. Nevertheless, Hulpia and Devos [19] explored the linkage between distributed leadership and teacher's organizational commitment through semi-structured interviews with teachers. They found that teachers were no more committed to the school when school leaders were highly accessible and encouraged their participation in decision making. In another study, Leithwood, Mascall, and Strauss [20] examined the relationship between distributed leadership and teacher's academic optimism. According to their findings, there was significant association between planned approaches to the distribution of leadership and high levels of academic optimism.

Regarding Ethiopia, there are some evidences that verify distributive leadership practice was not effective. Studies by Misgana [21] in secondary schools of Hadiya Zone related to principal distributive leadership, studies by Dejene [22] in Addis Abeba Unuversity, studies by Shimelis [23] in Secondary Schools of Aksum Town and Asrat [24] in primary schools of Deberk District have conducted on issues related to practice and challenges of distributed leadership. However, most of them are different in numerous ways from the current study. Based on their finding the above researchers identified the following problems, namely principal performances of practicing distributive leadership is inadequate, principals spending much of their time on administrative than academic issues and lack of collective responsibility for the goal attainment. However, they are different from this study in different ways. Firstly, they focused only on the role of principals on the practices of distributive leadership but they did not say anything about the role of school leaders (vice principals, unit leaders, supervisors) and teachers in exercising best practices distributive leadership played by all school stakeholders. Secondly, the researcher could not find the study conducted regarding distributive leadership in the area under study. Finally, empirical research investigation in relation to distributive leadership in secondary schools in Ethiopia is very rare. To the best of the researcher knowledge, no more studies were conducted in this area in relation to distributive leadership; this by itself initiates the researcher to undertake this study in order to identify practices and problems of exercising distributive leadership in public secondary schools of East Hararghe Zone, Oromia Regional State.

\section{Research Questions}

In the process of the study, the researcher attempted to answer the following basic research questions:
1. To what extent do secondary schools leaders and teachers participate in exercising distrbutive leadership best practice in public secondary schools of EHZ?

2. How do teachers and school leaders perceive the concepts of exercising distributive leadership under study area?

3. What are the major challenges in exercising distributive leadership best practices under study area?

\section{Objectives of the Study}

This section provides the objectives of the study. It compromises general objective and specific objectives.

\section{General Objective}

The general objective of this study is to examine practices and challenges of distributive leadership in public secondary schools of East Hararghe Zone, Oromia Regional State.

\section{Specific Objectives}

Specifically, the specific objective of this study was able to:

1. Examine the extent to which secondary schools leaders and teachers participate in exercising distributive leadership best practice under study area.

2. Identify how teachers and school leaders perceive the concepts of exercising distributive leadership in public secondary schools of EHZ.

3. Identify the major challenges in exercising distributive leadership best practices in public secondary schools of EHZ.

\section{Significance of the Study}

The results of this study may help create awareness among the secondary schools teachers, principals, vice principals, unit leaders, PTSA heads and supervisors by revealing what sort of distributive leadership competences do they lack while they were leading, progressing teaching-learning and sharing of experiences in their schools and how they fill these gaps in order to bring changes in their respective secondary schools. Therefore, the researcher strongly believes that the findings of this study report and recommendations have the following contributions.

The results of the study may help solve practical problems of distributive leadership in secondary schools under study area. It may provide a clear insight into the existing practices and pitfalls of distributive leadership for secondary schools education leadership police makers. It may also use as career development to the researcher. It may also be used as stepping-stone for those who want to engage further study on similar issue. The findings of the study may benefit EHZ secondary schools staff by giving soft 
copies and publishing it on international journals and it may serve as an input for different level of experts, that is, District Education Office, Zonal Education Office and Regional Education office.

\section{Delimitations of the Study}

The study was delimited to public secondary schools of East Hararghe Zone, Oromia Regional State. It was delimited to four selected Districts and one administrative town in the zone. They are, Kombolcha, Haramaya, Kersa and Gela Oda meyo Districts and Awaday administrative town. In the selected Districts, there were ten secondary schools. It was unaffordable and unmanageable to consider all schools for the study due to the reason of finance and time constraint. To make the study more manageable and consistent, six public secondary schools were selected by the researcher through using simple random sampling techniques. These schools are Adele, Kombolcha, keransa, kersa, Burqa and Awaday secondary schools.

The subject of the study were principals, vice principals, supervisors, PTSA heads, unit leaders and teachers. Because, the researcher consider them as they have more information about the distributive leadership practices in their school. The study merely focused on variables such as, practices, perception and problems of exercising distributive leadership. To make the study more manageable, frequency, percentage, mean, weighted mean, standard deviation and stepwise regression analysis was used. Questionnaire and interview were used as an instrument of data collection. In relation to sampling techniques, availability sampling techniques was employed for principals, vice principals, unit leaders, PTSA heads and supervisors whereas stratified random sampling techniques was employed for teachers.

\section{LIMITATION OF THE STUDY}

This study did not come to end without drawback. Some of the limitation that faced the researcher in conducting this study was lack of experiences, shortage of reference materials related to the study in Ethiopia and shortage of current literature in area of distributive leadership that could enrich the study. Another limitation was some of the teacher's respondents lack interest and being reluctant when they filled and returned the questionnaires. In addition, some of the supervisors were busy and had not enough time to respond interview and they were creating delaying tactics by giving appointment for different reasons. Due to this condition, the researcher consumed more time than previously allocated for data collection.

\section{Operational Definition of key Terms}

Distributive leadership is a leadership approach that emphasize on how the work of leadership takes place among the school stakeholders in the context of schools.
Perception is a belief or an image that school leaders and teachers sees or understands practices of distributive leadership.

Practices refer to the extent in which distributive leadership is exhibited.

Secondary school is refers to school level encompassing grades 9-10.

Problems refer to the extent that school leaders and teachers faced while exercising best practices of distributive leadership in schools.

\section{REVIEW OF RELATED LITERATURE}

The focus of this chapter is to review literatures that are relevant to the topic, distributive leadership practices and challenges in public secondary schools of East Hararghe zone, oromia regional state. Therefore, different type of books, journals and other related materials was reviewed and presented in the following part.

\section{Notion of Distributive Leadership}

The term distributed leadership means different things to different people. Distributed leadership is believed to have been used for the first time by Gibb [25], an Australian psychologist, who draw consideration to the dynamics of influence processes as they impact on the work of different groups. Gibb states that leadership should not be viewed as the domination of the individual but rather as communal functions among individuals. Harris, Leithwood, Sammons and Hopkinson [26] refer distributed leadership as the leadership idea of the moment. A review of the educational administration literature suggests that the concept of distributed leadership has been embraced with enthusiasm by educational researchers and scholars.

The notion of distributive leadership has also been used sometimes, collective leadership 27], collaborative leadership [28], co-leadership [29]. However, one Common across all these accounts is the idea that leadership is not the domination or responsibility of just one person, rather its collective and systemic understanding of leadership as a social process [30].

Distributive leadership basically involves both vertical and lateral dimensions of leadership practices. Distributed leadership encompasses both formal and informal forms of leadership practices within its framing, analysis and interpretation. It is mainly concerned with the co-performance of leadership and the reciprocal interdependencies that shape leadership practices [31].

From this statement, one can conclude that distributed leadership in any organization can fit all 
leadership dimensions with the intent of ensuring learning among schools leader in particular and organizational learning in general.

Distributive leadership is not something done by an individual to others or a set of individual actions through which people contribute to a group or organization; it is a group activity that works through and within relationships rather than individual action [11]. According to Gronn [32] distributive leadership offered to promise a new unit of analysis through which leadership could be understood in a holistic sense rather than simply aggregation of individual contributions. Some authors use the term shared leadership [33, 34] while others use the term distributive leadership [1]. At this point, there seems to be no clear conceptual differences between these approaches and different authors employ them interchangeably [35].

Besides the different terms employed, different authors depart in their conceptualizations of distributive leadership on different grounds, including the scope of participating agents in the leadership process. Some authors have paying attention on a single team or group of people as their unit of analysis [36], while others have taken a more open-systems approach taking the whole organization and even constituencies beyond the organizational boundaries as their unit of analysis [18]. However, regardless of these differences, most authors agree upon two principles as a basis concept of distributive leadership; first, leadership is a collective influence process to which several individuals contribute and secondly, leadership arises from the interactions of diverse individuals by which helps to form a group or a systems in which essential expertise is dispersed quality.

\section{Theoretical Origin of Distributive Leadership}

Distributive leadership is not a new concept at all [37]. It is a leadership approach used since the 50s $[25,1]$. While it is only really in the turn of the millennium that the concept of distributive leadership has been broadly embraced by scholars and practitioners, the origins of the concept go back quite a bit further. Oduro [38] suggests that distributive leadership date back $1250 \mathrm{BC}$, which is one of the most ancient leadership concepts recommended for fulfilling organizational goals through people. In terms of its theorization, Harris [31] proposes that it is an idea that can be traced back as far as the mid of twentieth and possibly earlier.

In educational sciences, researchers have started to focus on shared leadership since 1990 [1]. However, distributive leadership concept and approaches still continued to be explained under concepts such as self-leadership or super leadership or shared leadership [39]. According to Harris and Lambert [8] conceptual and functional discussions related to distributive leadership are still continuing in spite of organizational learning studies for more than twenty years. Still there are no clear identifications about how to familiarize distributive leadership positions, roles, practices and pictures in schools [40].

The inexistence task of distribution by the leader is myth in distributed leadership [8]. Since distributing tasks and duties as well as delegating positions is the most important power element in the leadership process. The most important and striking element that separate distributive leadership form the other leadership concepts is the fact that distributive leadership includes many elements related to education and is almost fed by educational environments. In this sense, Halverson and Clifford [41] calls distributive leadership as distributed instructional leadership and define the concepts as generation of an effective leaning climate by the leaders for teachers and others.

\section{Features of Distributive Leadership}

In reviewing related literature, the following distinctive features of distributive Leadership can be discerned [42, 43, 5].

\section{Form of Collective Leadership}

In a feature of distributive leadership, Silins and Mulford [44] describe as a sharing learning through teams of staff working together to argument the range of knowledge and skills available for the organization to change and participating future developments. The notion of distributive leadership is characterized as a form of collective leadership in which staff develops expertise by working collaboratively which incorporates the activities of various individuals in the organization who work together in the process of organizational change. A distributive outlook of leadership recognizes that leading organization engages multiple school leaders who share responsibilities and operate for a common goal. The basic perspective distributive leadership moves outlined by Yukl [45] as follow:

An alternative perspective to the heroic single leader, that is slowly gaining more adherents is to define leadership as a shared process of enhancing the individual and collective capacity of people to accomplish their work effectively instead of a heroic leader who can perform all essential leadership functions, the functions are distributed among different members of the team or organization [45].

\section{Recognizing Other People's Expertise}

Distributive leadership highlights leadership as an emergent property of a group or system of interacting individuals [1]. He identified the notion of distributive leadership as an emergent property of a group or network of individuals in which group members pool their expertise. It is not something done by an individual to others or a set of individual actions through which people contribute to a group or 
organization. When people work together in such a way; they pull together their abilities and expertise. The result is greater than the sum of their individual actions. Distributive leadership perspectives focuses on how leaders encourage and sustain conditions for successful schooling in interaction with others, rather than on what structures are necessary for success [18]. Generally, distributive leadership is about more than accounting for all leaders in an organization and adding up their actions to arrive at more wide-ranging account of leadership [5]. Therefore, by distributing responsibilities among staff, it is believed that every member of the organization has the capability to work as a leader [46].

\section{Openness of the Boundaries}

Distributive leadership suggests openness of the boundaries of leadership. This idea suggests that leadership should be accessible to organizational members who demonstrate their expertise in different aspects with leadership delivered to them [47]. Leadership is not restricted to a traditional definition that espouses only one person in charge of the organization [18]. Moreover, distributive leadership supports the idea that varieties of expertise are distributed across many ways. Various perspectives and capabilities found in individuals through the organization can concentrate a dynamic which represents more than the sum of the individual contributors. It is possible that people other than those experts will then adopt, adapt and improve them within a mutually trusting and supportive culture that expertise are distributed throughout the organization.

\section{Interactions among leaders, followers and situations}

A distributive leadership perception focuses on interactions among leaders, followers and their situations. Many scholars agreed that distributive leadership is not the same as dividing tasks among personnel who perform, defined and separate organizational roles; they believe that distributive leadership consists of dynamic interactions between multiple leaders, followers and situations [48]. Distributive perspective in schools frames leadership practice as a product of interaction among leaders, followers and the situations [5]. It tries to find out the interrelations of people and their situation through a wider lens where the individual knowledge and skill is measured as a matter of practice.

\section{Approaches of Distributive Leadership}

Distributive leadership approaches address lea dership along with teams, groups and organizational characteristics. As a result, distributive leadership approach claims that leadership at schools is a complex process [49] and includes many elements [37]. In this context, tasks and duties at schools are courses of duties that are too multi-dimensional and complex to be handled by a single person or school principal.

\section{Top Down Approach}

A number of studies summarized by Bennett et al., [11] which stated that, an important starting point towards the development of distributive leadership may be found in top down initiative from a strong leadership model where senior and formal leaders demonstrate significant influence on the school's culture. Many staff do not wish to be given leadership roles or have taken on responsibility beyond their own class teaching [50]. To distribute leadership, a strong leader is required to provide guidance and direction to make people feel confident $[51,50]$.

Formal leaders need to avoid overly controlling behavior and actively encourage and value innovative ideas from all members of the school. This means providing time, space and opportunities and knowing when to step back, enable staff members, to contribute and participate in decision making and establish concerted action. Distributive leadership does not mean that everybody leads, but that everybody has the potential to lead at some time. The degree to which informal leaders are involved in the process of distributive leadership may vary. A top down initiative may acknowledge and incorporate the existing informal power of leadership relationships into more formal leadership structures in ways seen as appropriate by the senior staffs that are creating the distributive structure or culture.

\section{Bottom Up Approach}

The initiative can also come from the bottom instead of top down. A bottom up approach is more likely to derive from individuals or groups within the organization who already are seen by colleagues as having a leadership role or when there is a lack of strong leadership [11]. According to NCSL [50] opportunistic and cultural distribution can be more characterized as bottom up forms of distribution. In opportunistic distribution, leadership is taken rather than given or planned. The success of such a bottom up approach may depend upon an attempt to bring into line formal and informal leaders within the organization. Cultural distribution is a form of distribution where leadership is not formally nor explicitly delegated, but a reflection of the entire school culture. This type of leadership is more intuitive, organic and spontaneous and is expressed in activities rather than in roles [50].

\section{Aspects of Distributive Leadership}

According to Spillane and Diamond [6] distributive leadership perception involves two aspectsthe leader plus aspect and the practice aspect.

\section{Leader Plus Aspect}

Distributive perspective acknowledges that the work of leading and managing schools involves multiple individuals. Leadership and management work involves more than what individuals in formal leadership positions do. People in formally designated 
leadership and management positions and those without any such designations can and do take responsibility for leading and managing the schools [6]. The leader-plus aspect recognizes that leading and running an organization involves multiple leaders. Leader-plus aspect alone is vital but not sufficient for explaining the complexity of leadership. The conceptual framework of distributed leadership developed by Spillane [5] moves beyond the leader-plus aspect. Distributive leadership means more than shared leadership. As leadership moves away from a command and control model to a more cultivate and coordinate model, the way that leadership is taught must change too.

\section{Practice Aspect}

The leadership practice aspect moves the focus from traditional leadership beyond an individual's actions to the interactions among leaders, followers and their situations [5]. A distributive leadership perception frames the practice aspect in a particular way; it frames as a product of school leaders interactions, followers and aspect of their situations. This distributive view of leadership shifts focus from leaders and other formal and informal leaders to the web of leaders, followers, and their situations that gives leadership practice [6].

\section{Practices of Distributive Leadership in Schools}

To study leadership practices, one has study the interplay between leaders, followers and situations. Ultimately, when distributive leadership becomes a part of the schools operating practices, school leaders have a clear understanding of which tasks should be distributed, who should be participate in distribution and the use of artifacts will guide the schools instructional program [52].

Leadership practices takes shape in the interactions of people and their situations, rather than from the actions of an individual leader [53]. A network of leaders should be created in order to create successful change [54]. They contend the leaders are both formal and informal in their roles, and they perform a variety of functions that are spread across the organization. With such a network, all members offer a unique perspective and serve as experts in their own rights. According to Gronn [42], Distributive leadership theory suggests the leaders should build leadership throughout the organization to include individuals and teams. Leaders set the tone to foster practices within the school that collaboration is paramount. With distributive leadership, the leadership is no longer central and supports the notion that everyone can demonstrate leadership with the organization [4].

Leithwood [55] determined that a school leader who actually uses the distributive leadership approaches engage staff in behaviors such things as: setting the school direction, establishing professional development initiatives, redesigning the organization, and managing instruction. Such leadership functions are an important part of the success of the school. In addition, Moller and Eggen [56] reported that the local and historical contexts of the schools influenced the methods and tools of distributed leadership that leaders employed. A few core practices that were used by school leaders who used distributed leadership included setting direction, developing people, and redesigning the organization to strengthen culture and build collaborative processes that facilitated distributive leadership.

\section{Distributive Leadership in Secondary Schools}

Secondary schools are subjected to a growing list of demands and expectations, which have an active interest in education for globalized work and informed citizenship. The key consumers in schools are students who are becoming more diverse and demanding in terms of their requirements and demands for services which fit their circumstances. These diverse needs and expectations of the society need sound leadership approaches that comply with these changes and expectations. According to Simkins [57] the role of leadership in secondary schools claims that the idea of leadership as being context-related and dispersed among people represents a more constructive framework to understand such organizations.

\section{Major problems of exefcsing Distributed Leadership Practices}

Contemporary literature points some difficulties, barriers, challenges and obstacles associated with distributive leadership in schools. Most researchers engaged with distributive leadership were worry of its efficiency in producing effective solutions to issues of distributive leadership in schools, since it was not a new idea that lacked clarity $[15,20]$, was a risky approach when leadership were designated to unskilled teachers [58, 59] and for some teachers, it is perceived as increased workloads and responsibilities [60].

Liljenberg [61] also argued that the usage and application of distributive leadership in the school context is not an easy task for school leaders to implement. Hence, practicing distributive leadership is considered as the major challenges for head teachers since it is a new approach that needed much study, especially on its effectiveness and the ways in which it constructed new leadership roles within each school. Empirically speaking, challenges and issues of distributive leadership within the educational context can be divided according to challenges in the school hierarchical structure, teacher competencies, the willingness to assume leadership roles, the concept of power sharing between head teachers with teachers in understanding of the practice of distributive leadership.

Fullan [62] stated that an external environmental force creating many challenges for secondary schools, these challenges require secondary schools to develop capable change cultures, and the 
broad base of leaders and leadership capabilities. The problems cover the need for greater access to educational institution, changing patterns of participation, changing expectations of students and growing diversity and consequent pressures on maintaining academic standards [63].

Another significant challenges faced by school leaders while practicing distributed leadership perspectives is the difficulties in finding teachers that manage to implement the relevant tasks that were delegated. For example, a study by $\mathrm{Abu}$ [64] in Bangladesh reveals that school leaders encountering difficulties in delegating their tasks to the right teachers suitable for the job. Apart from that, there were possibilities that teachers may take advantage of distributive leadership to challenge and resist the dominant policy agenda. To minimize the challenges of distributive leadership, operations were restricted to a small group of senior teachers; this led to separation among teachers, between leaders and followers.

Furthermore, Torrance [60] performed that some of the challenges of distributive leadership in schools were, most teachers and school leaders did not possess the talent and personality of a leader, Workloads of teachers and staff and the issue of perception towards legitimate appointments confuses the issue of leadership among their colleagues. In addition to this, some of the challenges of distributive leadership in schools were lack of communication, team work, and shared responsibilities, poor leadership ability, lack of commitment, lack of motivational skills and task overload is another major challenge.

\section{The Role of School Leaders in exercising practice}

DL

The role of the school leaders has been evolving during the last twenty years. In the late 1980s school leaders were expected to be the head instructional leaders in the buildings as well as be good managers by attending to all the details and completing paperwork on time, good supervisors of teachers and instructional staff and good bosses who kept the school faculty motivated, compliant, and cooperative [65]. The emergence of shared decision making resulted in the 1990s and school leaders who were open to sharing this responsibility were able to empower teachers. Currently there is a shift toward school administration focusing on developing a shared vision, improving school culture, increasing teacher leadership, transforming schools, and creating professional learning communities [65].

The role of school leaders is crucial in practicing distributive leadership, building leadership capacity and sharing leadership in the school. In schools were school leaders encourage traditional practices, emerging teacher leaders are snuffed out because of the positional challenges between teachers and administrators. In order for the school leaders to be an effective leader, school leaders must be first grounded in his values and then must share these with others [52]. For leadership to be distributed among many leaders, school leaders must build leadership capacity in teachers and provide support.

Blase and Blase [66] stated that, to empower teachers, school leaders must be model, build, and support a trusting environment, structure the school to allow for collaboration, use professional development and resources to support shared decision making, focus on teaching and learning, model professional behavior, praise teachers, and set up effective ways of communication.

\section{Conceptual Framework}

The conceptual framework is referred to as a set of broad ideas and principles taken from relevant fields of enquiry and used to structure a subsequent presentation [67]. It is used to clarify variables, concepts and to propose relationships among the concepts in this study. Distributive leadership practices might be affected by several challenges in schools such as challenges related with school leaders, teachers and both teachers and school leaders, absences of good practices and perception of teachers and school leaders on issues of distributive leadership. If the preceding factors are not adequately attended to, they can lead to unrealistic future plans which could result into too many consequences to the practices of distributive leadership such as lack of interaction among school leaders, followers and situations. These factors happened in the public secondary schools of East Hararghe Zone still a challenge as the findings in my studies.

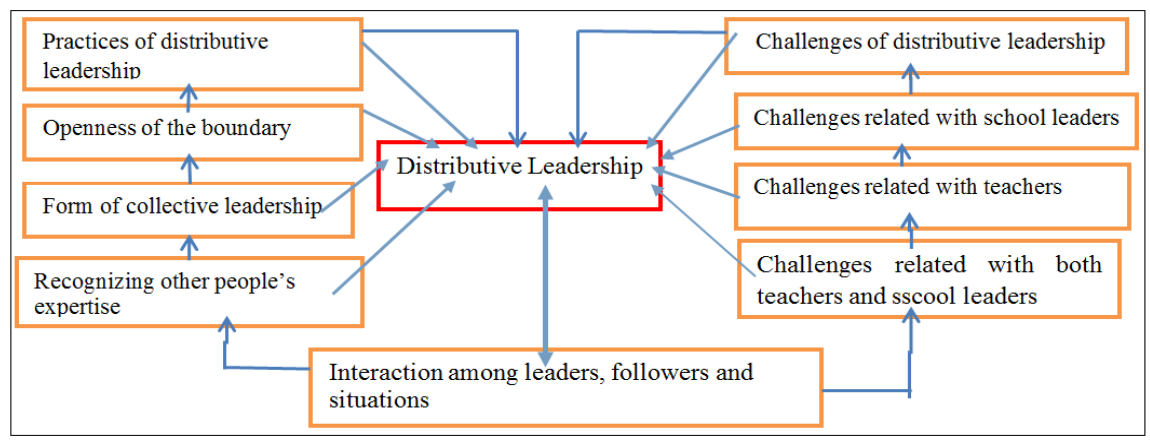

Fig-1: Conceptual Frame work of the study developed by the researcher 


\section{Summary of Review of Related Literature}

In the review of related literature, notion of distributive leadership, theoretical origin of distributive leadership, features of distributive leadership, approaches of distributive leadership, aspects of distributive leadership, practices of distributive leadership in schools, distributive leadership in secondary schools, challenges in practicing distributive leadership, the role of school leaders in practicing distributive leadership and possible strategies to overcoming in practicing distributive leadership were discussed.

\section{RESEARCH DESIGN AND METHODOLOGY}

This section of study deals with description of the study area, research design and method, sources of data, population, samples size and sampling technique, data collection instruments, data collection procedures, methods of data analysis and Ethical consideration.

\section{Description of the Study Area}

This study was conducted in East Hararghe zone, Oromia Regional State, which is geographically located in eastern part of Ethiopia and it is one of the 19 zones in the Oromia Regional State. In the zone, there are twenty Districts and four administrative towns. Out of them four Districts and one administrative town was selected for the study; Kombolcha, Haramaya, Gola Oda and kersa Districts and Awaday administrative town. It lies between $8^{\circ} 29^{\prime}$ to 59.99" north latitudes and $40^{\circ} 39^{\prime}$ to $59.99^{\prime \prime}$ east longitudes. It shares boundaries to the southwest by Shebelle River which separates from Bale, to the West by West Hararghe, to the North by Dire Dawa and to the North and East by Somali region. Harari Regional State is entirely surrounded by East Hararghe zone. The zone capital is Harar, which is $526 \mathrm{~km}$ far away from the Ethiopian capital, Addis Abeba [68].

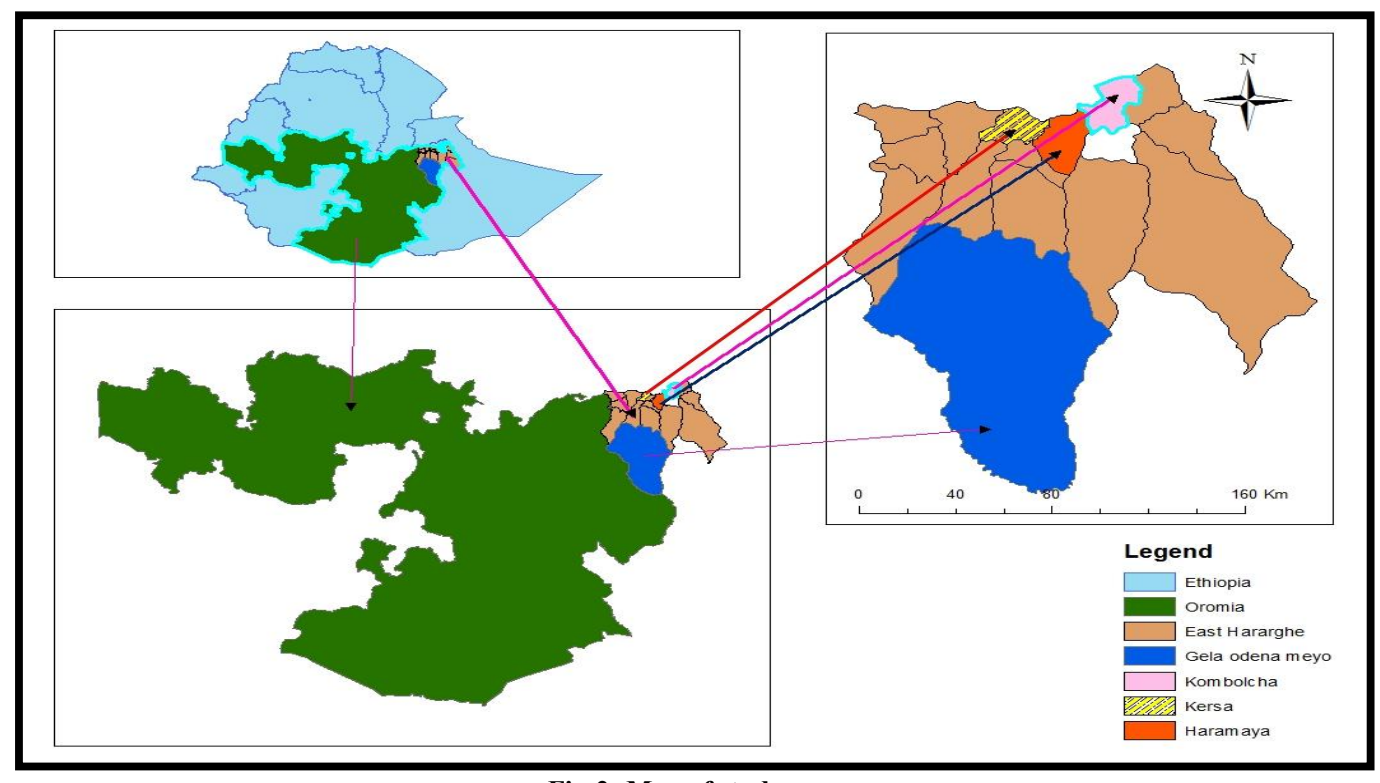

Fig-2: Map of study area

Based on the census conducted by the central statistical agency of Ethiopia 2007 (CSA), East Hararghe zone has a total population of $2,723,850$, of whom 1,383,198 are men and 1,340,652 women with an area of $17,935.40 \mathrm{~km}^{2}$. In the zone there were three largest ethnic groups, Oromo (93.69\%), Amhara (4.16\%), and Somali (1.84\%); all other ethnic groups made up $0.31 \%$ of the population. Afan Oromo was spoken as a first language by $92.57 \%, 4.02 \%$ spoke Amharic, and $3.05 \%$ spoke Somali; the remaining $0.36 \%$ spoke all other primary languages. The majority of the inhabitants were Muslim, with $95.28 \%$ of the population, while $4.51 \%$ professed Ethiopian Orthodox Christianity. In terms of weather conditions, the zone contains three agro-ecological zones, Dega (highlandselevations above 2,300m), woina Dega (midlands elevations between 1,500 and 2,300m) and kolla (lowlands - below 1,500m).
According to a May 24, 2004 World Bank memorandum, concerning education $53 \%$ of all eligible children are enrolled in primary school and only $10 \%$ of children were enrolled in secondary schools in east hararghe zone. In terms of their major crops grown in the area were sorghum, maize, ground nut, potato, onion, Khat and other vegetable crops. Livestock are important components of the farming system for consumption and source of income. The livestock rearing is mostly not greater than four herd per household because of shortage of grazing land, the Animal feeding method is most commonly have experienced cut and carry system [68].

\section{Research Design}

For this study, explanatory sequential design will be employed, because an explanatory sequential mixed methods design also called a two-phase model consists of first collecting quantitative data and then 
collecting qualitative data to help explain or elaborate on the quantitative results [69]. Both, quantitative and qualitative approach will be employed, because, both approach is suitable for social and behavioral sciences as a distinct research which is used to cover a basic deficiencies and description of the study [70]. In addition, this approach considered as a tool to triangulate the result of single approach through multiple methods [71]. Quantitative approach is selected because it is viewed as an effective to gather large data and comprehensive issues at a specified period of time [72]. While the qualitative approach is selected based on the assumption that it enables the researcher generate meanings and phenomena within the real context of the research participants and to fill the gap left by the quantitative one [73]. Therefore, both quantitative and qualitative approaches will employed for this study in order to make the study more reliable.

\section{Sources of Data}

In this study both primary and secondary sources of data were employed to get valid and reliable information about the practices and problems of exercising distributive leadership in public secondary schools of East Hararghe Zone, Oromia Regional State.

\section{Primary Sources}

A primary source was used to get first-hand information concerning the practices and problems of exercising distributive leadership in the study area. Accordingly, the primary data were collected from schools leaders (principals, vice-principals, PTSA heads, supervisors and unit leaders) and teachers.

\section{Secondary Sources}

The secondary sources of data was used to strengthen the primary sources, which is obtained from written minutes that show what leadership decision made, discussed documents, and annual reports available in schools.

\section{Population, Sample Size and Sampling Techniques}

According to East Hararghe Zone Education Departments first quarter report of 2018, there were twenty Districts, four Administrative Town and fifty eight secondary schools in the Zone. Since the scope of the research and number of the population is wide and large in numbers. Therefore, the researcher selected four Districts and one administrative town by using simple random sampling techniques. Accordingly, the selected districts and administrative town were, Gola Oda, Kombolcha, Kersa and Haramaya districts and Awaday Administrative Town. In the selected districts and administrative town, there were ten secondary schools of which six schools were selected using simple random sampling techniques, because the area of the study is very wide and number of population is large. Therefore, Adele, Kombolcha, keransa, kersa, Burqa and Awaday secondary schools were selected. In the selected schools, there are 224 teachers, 5 supervisors, 6 principals, 6 vice-principals, 12 unit leaders and 6 PTSA heads.

In order to decide upon sample size of respective subjects, Yamane [74] formula of sample size was used. Accordingly,

$$
\mathrm{n}=\frac{N}{1+N(e)^{2}}
$$

Where,

$$
\begin{aligned}
& \mathrm{N}=\text { population } \\
& \mathrm{n}=\text { sample size } \\
& \mathrm{e}^{2} \leq(.05)^{2}
\end{aligned}
$$

Accordingly, sample size for teachers was decided as;

$$
\begin{aligned}
& \mathrm{n}=\frac{N}{1+N e^{2}}=\frac{224}{1+224(.05)^{2}} \\
& \mathrm{n}=\frac{224}{1+224(.0025)}, \mathrm{n}=\frac{224}{1+0.56}, \mathrm{n}=\frac{224}{1.56}=144 \\
& \mathrm{n}=144 \text { teachers }
\end{aligned}
$$

In this way, the respondents were selected from respective schools through different sampling methods. Accordingly, data was collected from six categories of respondents including five supervisors, six principals, six vice-principals, twelve unit leaders, six PTSA heads and one hundred forty four teachers. As a result, availability sampling technique was employed for supervisors, principals, vice principals, PTSA heads and unit leaders from the sampled schools due to their being few in number and their direct involvement in the practices of school leadership. In addition, a stratified random sampling technique was used to select teachers from each school on the basis of their experiences in their school. This is because; teachers are very close to the overall instructional activities of schools. 
Table-1: Distribution of Populations, Sample Size and Sampling Techniques

\begin{tabular}{|l|c|c|c|c|c|c|}
\hline No & Principals & $\begin{array}{l}\text { Vice } \\
\text { principals }\end{array}$ & Supervisors & Unit leaders & PTSA & Teachers \\
\cline { 2 - 7 } Name & $\begin{array}{l}\text { Population } \\
\text { Sample \% }\end{array}$ & $\begin{array}{l}\text { Population } \\
\text { Sample \% }\end{array}$ & $\begin{array}{l}\text { Population } \\
\text { Sample \% }\end{array}$ & $\begin{array}{l}\text { Population } \\
\text { Sample \% }\end{array}$ & $\begin{array}{l}\text { Population } \\
\text { Sample \% }\end{array}$ & $\begin{array}{l}\text { Population } \\
\text { Sample \% }\end{array}$ \\
\hline 1. Adele & 11100 & 11100 & 11100 & 22100 & 11100 & 291964 \\
\hline $\begin{array}{l}\text { 2. } \\
\text { Kombolcha }\end{array}$ & 11100 & 11100 & 11100 & 22100 & 11100 & 603864 \\
\hline 3. Keransa & 11100 & 11100 & ---- & 22100 & 11100 & 312064 \\
\hline 4. Kersa & 11100 & 11100 & 11100 & 22100 & 11100 & 291964 \\
\hline 5. Burqa & 11100 & 11100 & 11100 & 22100 & 11100 & 231564 \\
\hline 6. Awaday & 11100 & 11100 & 11100 & 22100 & 11100 & 523364 \\
\hline Total & 66100 & 66100 & 55100 & 1212100 & 66100 & 22414464 \\
\hline $\begin{array}{l}\text { sampling } \\
\text { SRS }\end{array}$ & $\begin{array}{l}\text { Availability } \\
\text { sampling }\end{array}$ & $\begin{array}{l}\text { Availability } \\
\text { sampling }\end{array}$ & $\begin{array}{l}\text { Availability } \\
\text { sampling }\end{array}$ & $\begin{array}{l}\text { Availability } \\
\text { sampling }\end{array}$ & $\begin{array}{l}\text { Availability } \\
\text { sampling }\end{array}$ & $\begin{array}{l}\text { Stratified random } \\
\text { sampling }\end{array}$ \\
\hline
\end{tabular}

SRS $=$ Simple Random Sampling, \% = Percentage

\section{Data Collection Instruments}

To obtain the data, which answers the stated research questions and achieve the objective of the study, questionnaires and interview was used by the researcher as an instrument of data collection. So, using different types of instruments, the researcher was get reliable and suitable data to minimize error.

\section{Questionnaire}

Questionnaires is a valuable tool for gathering data which helps save time, encourage objectivity, provide rapid analysis, obtain information about certain conditions, practice inquiry in to opinion and attitude of individuals, groups and feedback to the researcher [75]. The questionnaire has contained two parts that designed to address the basic question of the study. The first part was background of the respondents which includes, sex, age, work experiences, academic qualification and their position in school; part two encompasses a closed-ended and open-ended question which contains 39 items regarding distributive leadership practices, perception, and major problems for effective practices of exercising distributive leadership under study area.

In order to get relevant information about the practices and problems of exercising distributive leadership under study area, the researcher used both open-ended and closed-ended questionnaires for $144(64 \%)$ teachers and $30(100 \%)$ school leaders (principals, vice principals, PTSA heads and unit leaders) of the sampled schools. This closed-ended questionnaire were in five point likert scale ranging from strongly disagree to strongly agree and very low to very high while open ended questionnaire was designed for respondents to gather valuable additional information about the research problem. Kumar [76] suggested that, using open-ended and closed-ended questionnaire minimizes the risk instead of using one of them depending up on the type of question items.

Pilot study was conducted for all data collection instruments to test their validity and reliability before the real field work is undertaken. It was conducted on 30 teachers in the water secondary school which were selected purposively out of the sample schools. The reliability was checked by using Cronbach Alpha. A reliability coefficient (alpha) of 0.70 and above is considered acceptable reliability. Therefore, the Cronbach's alpha reliability coefficient was obtained to check for internal consistency for all items. Accordingly, the calculated Cronbach's Alpha coefficient for this study was $0.74,0.78$, and 0.76 for the first; second and third sections of the questionnaire (see appendix IV). In addition to this, face, content and language validity was checked by major advisor and coadvisor. As a result of pilot study minor modification was made in terms of language, format or style and content.

\section{Interview Guide}

The other instrument to be used for the collection of primary data for the study is an interview. It is helpful to supplement the information gathered through other instruments, as well as for the clarification of some unforeseen information. It is also being used to cross-check the responses obtained through questionnaire and it let the interviewee to express his or her feeling freely and knowledge of people in a program in depth [75].

In order to obtain deeper information related to the practices and problems of exercising distributive leadership, Semi-structured interview was prepared and employed to $5(100 \%)$ supervisors to collect factual and detail information from study area. From each sampled schools one supervisor was selected. Thus, a total of five supervisors were involved in the interview at different times and places. Seven interview questions were prepared for all participants of the sample schools. Regarding the process of interview, it was conducted by Afan Oromo language in order to make the interview questions easy to understand for the respondents and to obtain more reliable and valid information regarding the study and supported by Audio (tape recorders). For each interviewee, 30 minutes was given. The recorded 
data was categorized based on similarities of responses and then transcribed into English language.

\section{Data Collection Procedures}

In order to get better picture of the study, first, the researcher visited the zonal education office to discuss the purpose of research and showing the letter of cooperation from Haramaya University and asked the zonal education office to write a letter to the study area. Then the researcher visited the school principal and vice-principal to discuss the purpose of the research with them via showing the letter of permission from the university and the zonal education office. Then, in order to make sure the suitability of the instruments, pilot test was conducted for instructors in the study area who were not included in the sample of the study. Second, after improving the data gathering instruments on the basis of the results of the pilot test, the final questionnaires was administered to sample teachers in the selected schools.

The participants were allowed to give their own answers to each item independently and the data collectors was closely assist and supervise them to solve any confusion regarding to the instrument. Finally, the questionnaire was collected and data analysis was made by the researcher.

\section{Methods of Data Analysis}

The data was analyzed both quantitatively and qualitatively. The analysis of data was based on the responses collected through closed-ended questionnaires, interview and open-ended questionnaire. The data collected through closed-ended questionnaire were organized, tabulated, tallied, and filled in to SPSS version 20 to assess the practices and challenges of distributive leadership. Both descriptive and inferential statistics were used to analyze the data. From descriptive statistics, frequency count and percentages were employed to analyze the demographic characteristics of the respondents whereas the mean scores, weighted mean and standard deviation were computed for quantitative variables against each item score so as to describe dispersion or variability and to identify the extent of school leaders and teachers in exercising distributive leadership best practices. In addition, Regression analysis was conducted to know by how much the independent variable explains the dependent variable.

The stepwise regression analysis is an analysis of association in which the effects of two or more independent variables on a single interval scaled dependent variable are investigated simultaneously [77]. The result of this analysis indicates how well a set of variables is able to predict the dependent variable. Furthermore, it shows how much unique variance in the dependent variable is explained by each of independent variables [78].
The interpretation is made for all five point scale measurements based on the following mean score results: [1.00-1.50) as strongly disagree/very low, [1.502.50) as Disagree/ low, [2.50-3.50) as undecided/ medium, [3.50-4.50) as Agree / high and [4.50-5.00] as strongly agree/ very high [79]. In addition to the above methods of data analysis, data obtained through interview and open-ended questionnaire was analyzed and interpreted qualitatively by narrating the ideas provided by the respondents based on ideas raised and the result were triangulated with quantitative findings. Finally, the findings were summarized; concluded and suggested recommendations were forwarded.

\section{Ethical Considerations}

To make the research process professional, ethical consideration was made. The researcher informed the respondents about the purpose of the study i.e. purely for academic; the purpose of the study were also introduced in the introduction part of the questionnaire and interview guide to the respondents and confirm that subject's confidentiality was protected. In addition to this, the anonymity of the participants of the study is protected and was inform that their participation in the study is based on their consent. From very beginning the researcher was inform the respondent about the purpose of the study via considering research ethics in data collection, analysis and recommendations. Furthermore, all the materials used for this research have been acknowledged. Finally, a copy of the final report could be given to the organization if necessary.

\section{RESULTS AND DISCUSSIONS}

This chapter attempts to present the analysis and interpretation of data collected from sample population, East Hararghe Zone public secondary schools through questionnaires and interviews. It consists of two major parts. The first part indicates general characteristics of the respondents in relation to their age, sex, qualification and work experience were tabulated and analyzed as indicated under Table-2 through frequency and percentage and the second part deals with the presentation, analysis and interpretation of data through mean score, weighted mean, standard deviation and stepwise regression analysis. The quantitative as well as qualitative data were integrated in this chapter. The qualitative data were used as complementary to the quantitative data. Therefore, the qualitative data includes the data collected through interviews and open-ended questions whereas, the quantitative data includes the data which were collected through closed- ended questionnaires.

Questionnaires were prepared and administered for 30 school leaders (6 school principals, 6 vice principals, 6 PTSA heads and 12 unit leaders) and 144 teachers. Therefore, the total number of questionnaires distributed to school leaders and teachers were 35 closed ended and 4 open ended questions. Out 
144 sample teachers and 30 school leaders, 120(83.3\%) of teachers and $30(100 \%)$ of school leaders were filled and returned the questionnaires to the researcher. In addition, to supplement the information gathered through questionnaire, interviews were held with $5(100 \%)$ supervisors.

Finally, in analyzing the data, different statistical techniques and procedures were used. Initially, the data collected through questionnaire were coded and inserted in to SPSS for analysis. Then the means for the two groups of respondents (teachers and school leaders) were identified and analysis was done using mean, weighted mean and standard deviation of the two groups of respondents.

\section{Background of the Respondents}

Under this sub topic, sex, age, academic qualification and work experiences of the respondents were presented. The following Table-

2 shows the distribution of respondents' characteristics to be discussed in details.

Table-2: Respondents Backgrounds

\begin{tabular}{|c|c|c|c|c|c|c|c|c|c|c|c|c|c|}
\hline \multirow[t]{2}{*}{ No } & \multirow[t]{2}{*}{$\begin{array}{l}\text { Variable } \\
\text { s }\end{array}$} & \multicolumn{2}{|c|}{ Principals } & \multirow{2}{*}{$\begin{array}{l}\begin{array}{l}\text { Vice } \\
\text { principals }\end{array} \\
\mathrm{F}\end{array}$} & \multirow[b]{2}{*}{$\%$} & \multicolumn{2}{|c|}{$\begin{array}{l}\text { Supervisor } \\
\text { S }\end{array}$} & \multicolumn{2}{|c|}{$\begin{array}{l}\text { Unit } \\
\text { leaders }\end{array}$} & \multicolumn{2}{|c|}{$\begin{array}{l}\text { PTSA } \\
\text { PTS }\end{array}$} & \multicolumn{2}{|c|}{ Teachers } \\
\hline & & $\mathrm{F}$ & $\%$ & & & $\mathrm{~F}$ & $\%$ & $\mathrm{~F}$ & $\%$ & F & $\%$ & $\mathrm{~F}$ & $\%$ \\
\hline 1. Sex & $\begin{array}{l}\mathrm{M} \\
\mathrm{F} \\
\end{array}$ & 6 & 100 & 6 & 100 & 5 & 100 & 12 & 100 & 6 & 100 & $\begin{array}{l}103 \\
17\end{array}$ & $\begin{array}{c}85.83 \\
14.17\end{array}$ \\
\hline & Total & 6 & 100 & 6 & 100 & 5 & 100 & 12 & 100 & 6 & 100 & 120 & 100 \\
\hline 2 Age & $<25$ & & & 1 & 16.7 & & & 1 & 8.4 & & & 12 & 10 \\
\hline & $25-30$ & 1 & 16.7 & & & 3 & 60 & 4 & 33.3 & & & 36 & 30 \\
\hline & $30-35$ & 3 & 50 & 4 & 66.6 & 1 & 20 & 4 & 33.3 & 3 & 50 & 53 & 44.16 \\
\hline & $35-40$ & 2 & 33.3 & & & 1 & 20 & 3 & 25 & 2 & 33.3 & 13 & 10.84 \\
\hline \multirow{12}{*}{ 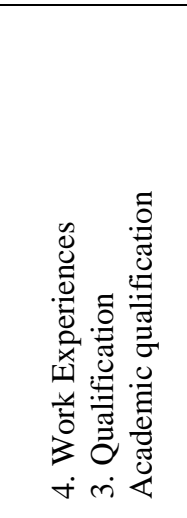 } & 40 above & & & 1 & 16.7 & & & & & 1 & 16.7 & 6 & 5 \\
\hline & Total & 6 & 100 & 6 & 100 & 5 & 100 & 12 & 100 & 6 & 100 & 120 & 100 \\
\hline & Diploma & & & & & & & & & 6 & 100 & & \\
\hline & Degree & 2 & 33.3 & 5 & 83.3 & 4 & 80 & 12 & 100 & & & 108 & 90 \\
\hline & Masters & 4 & 66.7 & 1 & 16.7 & 1 & 20 & & & & & 12 & 10 \\
\hline & Total & 6 & 100 & 6 & 100 & 5 & 100 & 12 & 100 & 6 & 100 & 120 & 100 \\
\hline & $<5$ & 1 & 16.7 & 1 & 16.7 & & & & & 6 & 100 & 17 & 14 \\
\hline & $5-10$ & 2 & 33.3 & 4 & 66.6 & 2 & 40 & 2 & 16.7 & & & 44 & 36.7 \\
\hline & $10-15$ & 3 & 50 & 1 & 16.7 & 2 & 40 & 5 & 41.6 & & & 26 & 21.7 \\
\hline & $15-20$ & & & & & & & 2 & 16.7 & & & 21 & 17.5 \\
\hline & Above 20 & & & & & 1 & 20 & 3 & 25 & & & 12 & 10 \\
\hline & Total & 6 & 100 & 6 & 100 & 5 & 100 & 12 & 100 & 6 & 100 & 120 & 100 \\
\hline
\end{tabular}

As presented on the above Table-2 item 1, $6(100 \%)$ of principals, $6(100 \%)$ of vice principals, $5(100 \%)$ of supervisors, $12(100 \%)$ of unit leaders and $6(100 \%)$ of PTSA were male respondents. Regarding teachers respondents, $103(85.83 \%)$ and 17 (14.17\%) of teacher respondents were males and females respectively. From this, one can realize that the number of females in the teaching profession is much lower than males in the sampled schools and the leadership position and supervisory position of secondary schools were controlled by males in the sampled schools.

As can been seen in Table-2 item 2, which shows the age distribution of principals, vice principals, supervisors, unit leaders, PTSA heads and teachers. As the data indicates the majority of principal respondents $3(50 \%)$ were in the age range of $30-35$ and $2(33.3 \%)$ were in the age range of $35-40$ and $1(16.7 \%)$ were in the age range of 25-30 and there were no principal respondents in the age range of less than 25 and above 40 years in the sample schools under study area. Regarding vice principal respondents, the distribution of age range is $1(16.7 \%), 4(66.6 \%)$ and $1(16.7 \%)$, is between the age range of less than 25, 30-35 and above 40 years respectively. And there were no vice principal's respondents in the age range of 25-30 and $35-40$. In relation to supervisors, the age range 25-30 is the highest which is $3(60 \%)$ and followed by the age range $30-35$ and $35-40$ that is $1(20 \%)$ and $1(20 \%)$ respectively and there were no supervisors in the age range of less than 25 and above 40 years in the sample schools. In relation to unit leaders respondents the distribution of age range is $1(8.4 \%), 4(33.3 \%), 4(33.3$ $\%)$ and $3(25 \%)$ is between the age range of less than 25 , 25-30, 30-35 and 35-40 respectively. Regarding PTSA heads the highest age respondents were between the age range of $30-35,35-40$ and above 40 , which is $3(50 \%)$, $2(33.3 \%)$ and $1(16.7 \%)$ respectively. Regarding the teachers respondents $12(10 \%), 36(30 \%), 53(44.16 \%)$, $13(10.84 \%)$ and $6(5 \%)$ of the teacher respondents were found to be between the age ranges of less than 25,25 $30,30-35,35-40$ and above 40 respectively. Thus, there would no barriers that the age differences might have challenges in practicing distributive leadership. 
As indicated in Table-2 item 3, which shows the academic qualification of respondents, about $2(33.3 \%)$ of principals, $5(83.3 \%)$ of vice principals, $4(80 \%)$ of supervisors, $12(100 \%)$ of unit leaders and $108(90 \%)$ of teachers were first degree holders respectively, while the rest relatively $4(66.7 \%)$ of principals, $1(16.7 \%)$ of vice principals, $1(20 \%)$ of supervisors and $12(10 \%)$ of teachers were have masters holders respectively in the sampled schools. In relation to PTSA heads, 6(100\%) of respondents were has diploma holders. This indicates that there was much variation in qualification between teachers and school leaders under study area. According to guidelines of MoE [80] the requirement criteria to be secondary schools principals, vice principals and supervisors they required to have second degree holders in the required field study like educational administration, educational management and leadership.

As can been from Table-2 item 4, which shows work experiences of respondents, 1(16.7\%) of principals, $1(16.7 \%)$ of vice principals, $6(100 \%)$ of PTSA heads and $17(14 \%)$ of teachers were ranged in the service year of less than 5 year and there were no supervisors and unit leaders in the age range of less than 5 year services. In the same table of the above, $2(33.3 \%)$ of principals, $4(66.6 \%)$ of vice principals, $2(40 \%)$ of supervisors, $2(16.7 \%)$ of unit leaders and $44(36.7 \%)$ of teachers were in the age range of 5-10 year of experiences and in this year services there were no PTSA heads respondents. In addition to this, in the year services of $10-15$, there were $3(50 \%)$ of principals, $1(16.7 \%)$ of vice principals, $2(40 \%)$ of supervisors, $5(41.6 \%)$ of unit leaders and $26(21.7 \%)$ of teachers were there. Relatively few of the respondents $2(16.7 \%)$ of unit leaders and $21(17.5 \%)$ of teachers were in the average year services of 15-20 and there were no principal, vice principals, supervisors and PTSA heads in the age range of 15-20. Lastly $1(20 \%)$ of supervisors, $3(25 \%)$ of unit leaders and $12(10 \%)$ teachers were in the age year services of above 20. Similarly, there were no principals, vice principals and PTSA heads above the year services of 20 in the sample schools under study area. From this one can conclude that, most of the respondents were young and some of them were elders. So, in researcher's view, most of the respondents were in the active age ranges and have the ability to participate in practicing distributive leadership.

\section{Extent of Exercising Distributive Leadership Practice}

Teachers and school leaders were asked to rate their extent of exercising distributive leadership practices in their respective schools.

\section{Extent of DL practices regarding its openness of the boundaries}

For the respondents questionnaire which had five rating scale and stepwise regression analysis was analyzed and the result was summarized and discussed in the following Table $3 \& 4$.

Table-3: Distributive Leadership Practices in Relation to its Openness of the Boundaries

\begin{tabular}{|l|l|l|l|l|l|l|}
\hline No & Items & \multicolumn{2}{|l|}{$\begin{array}{l}\text { Teachers } \\
\text { N=120 }\end{array}$} & \multicolumn{2}{|l|}{$\begin{array}{l}\text { School leade } \\
\mathbf{N}=\mathbf{3 0}\end{array}$} & $\begin{array}{l}\text { Total } \\
\mathbf{N = 1 5 0}\end{array}$ \\
\cline { 3 - 7 } & & $\mathbf{M}$ & $\mathbf{S D}_{\mathbf{1}}$ & $\mathbf{M}$ & $\mathbf{S}$ \\
\hline 1 & $\begin{array}{l}\text { Teachers are significantly involved in decision that affects best } \\
\text { practice of distributive leadership in school freely. }\end{array}$ & 1.59 & 0.69 & 2.30 & 1.36 & 1.73 \\
\hline 2 & $\begin{array}{l}\text { Teachers have a chance to participate } \\
\text { in decision making activities in their respective school to exercise } \\
\text { best practices freely without any restriction. }\end{array}$ & 2.18 & 0.60 & 2.26 & 0.58 & 2.19 \\
\hline 3 & $\begin{array}{l}\text { Teachers play a major role to practice } \\
\text { distributive leadership in their school freely. }\end{array}$ & 1.90 & 0.73 & 2.83 & 0.74 & 2.08 \\
\hline
\end{tabular}

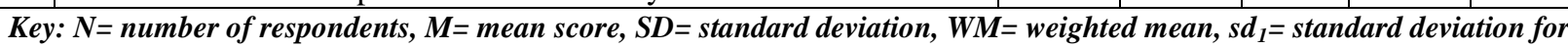
teachers, $s d_{2}=$ standard deviation for school leaders.

As indicated in Table-3 item 1, the mean score (1.59) for teachers and (2.30) for school leaders were identified that there were at low level on the issue of teachers are significantly involved in decisions that affect best practices of distributive leadership in school freely. Generally, the weighted mean score (1.73) indicated that both teachers and school leaders were at low level on the issue of teachers are significantly involved in decisions that affect best practices of distributive leadership in school freely. In addition to this, the standard deviation $\left(\mathrm{sd}_{1}=0.69\right.$ and $\left.\mathrm{sd}_{2}=1.36\right)$ for teachers and school leaders indicated that there were little variability among respondents on their reply. This implies that teacher's involvement in decision making activities regarding distributive leadership practices was low.

As expressed in Table-3 item 2, the mean score (2.18 and 2.26) for teachers and school leaders were identified that, there were at low level regarding the issues of teachers have a chance to participate in decision making activities in their respective schools to exercise best practices freely without any restriction. Generally, with the weighted mean scores (2.19) implies that both teachers and school leaders respondents were score low on the area of teachers have 
a chance to participate in decision making activities in their respective schools to exercise best practices freely without any restriction. Besides to this, the standard deviation $\left(\mathrm{sd}_{1}=0.60\right.$ and $\left.\mathrm{sd}_{2}=0.58\right)$ for teachers and school leaders indicated that there were no variability among respondents in their reply. This expresses that teachers in the schools have less opportunity to participate in decision making activities in their respective schools in relation to distributive leadership best practices beyond their own class room under study area.

As can be seen from Table-3 item 3, the mean score (1.90) and (2.83) for teachers and school leaders were at low and medium level on the issues of teachers play a major role in practicing distributive leadership in their schools freely. Generally, the weighted mean score (2.08) for both group of respondents were recognized at low level regarding the issue stated that, teachers play a major role in practicing distributive leadership in their schools freely. In addition to this, the standard deviation $\left(\mathrm{sd}_{1}=0.73\right.$ and $\left.\mathrm{sd}_{2}=0.74\right)$ for teachers and school leaders indicated that, there were no variability among the respondents regarding the issues of teachers play a major role to practice distributive leadership in their schools. Therefore, one can understand that, the roles of teachers in school were progressing teaching and learning process rather practicing distributive leadership under study area. In contradicts to this ideas, The days of the school leaders as the only actors to practices different activities in the schools are over, everyone in the school has the right, responsibility and ability to be a leader and practices and influence every activities [81]. With regard to the above descriptive analysis, the stepwise regression analysis was discussed as follows.

Table-4: Regression Analysis $(n i=150, P<0.05)$ on DL Practices Regarding its Openness of the Boundaries

\begin{tabular}{|c|c|c|c|c|c|}
\hline \multicolumn{6}{|l|}{ Coefficients } \\
\hline \multirow{3}{*}{$\begin{array}{l}\text { Model } \\
\text { 1. Constant }\end{array}$} & \multirow{3}{*}{$\begin{array}{ll}\mathbf{R} \\
0.49\end{array}$} & \multirow{3}{*}{$\begin{array}{l}\mathbf{R}^{2} \\
0.24\end{array}$} & \multicolumn{2}{|c|}{ USC } & \multirow{3}{*}{$\frac{\text { SC }}{\text { Beta }}$} \\
\hline & & & $\mathrm{B}$ & SE & \\
\hline & & & 0.56 & 0.18 & \\
\hline $\begin{array}{l}\text { Teachers have a chance to participate in decision making activities in their respective } \\
\text { school to exercise best practices freely without any restriction. }\end{array}$ & & & 0.60 & 0.09 & 0.39 \\
\hline Teachers play a major role to practice distributive leadership in their schools freely. & & & 0.54 & 0.08 & 0.49 \\
\hline
\end{tabular}

Key: $R=$ coefficient of correlation, $R^{2}=$ coefficient of determination, $U S C=$ unstandardized coefficient, $S C=$ standardized coefficient, $S E=$ standardized error, $n i=$ sample seize, $B=$ slope

As per Table-4 reveals, the regression analysis on the extent of distributive leadership practices regarding its openness of the boundaries in providing teachers chance to participate in decision making activities in their respective schools to exercise best practices freely without any restriction and Teachers play a major role to practice distributive leadership in their schools freely measured by regression coefficient (0.56) was contributing $24 \%$ to deteriorating distributive leadership practices as measured by the stepwise regression analysis coefficient $\left(\mathrm{R}^{2}\right) * 100$. The result means that $24 \%$ of the variation on the dependent variable is accounted for the variation in the independent variable whereas the rest unexplained variable $\left(1-\mathrm{R}^{2}\right) * 100$ were contributing $76 \%$ to deteriorating to distributive leadership practices. This means the rest of variation $76 \%$ is unexplained. The accompanying computer printout shows a regression equation that predicts the extent to which teachers have a chance to participate in decision making activities in their respective schools to exercise best practices freely without any restriction $\left(\mathrm{x}_{1}\right)$ and Teachers play a major role to practice distributive leadership in their schools freely $\left(\mathrm{x}_{2}\right)$ that affect distributive leadership practices were expressed by statistically significant independent variables were $\mathrm{Y}=0.56+0.60 \mathrm{x}_{1}+0.54 \mathrm{x}_{2}$ where 0.56 is constant. The positive slopes of the two variable respectively were $(0.60$ and 0.54$)$ which used to indicate that as per a unit increase of the independent variable would tends to increase distributive leadership practices.

Similarly, in supporting the above finding an interview was conducted with schools supervisors. During the interview session, the researcher asked the secondary schools supervisors how the teachers are engaged in decision-making activities beyond their own class-room activities in their school. Some of respondents' responses were similar. One of the interviewee supervisors said:

Teachers in schools are involved in decision making activities at department level, specially when there is problem between teachers and students during class room teaching and learning process and sometimes when there is discussion of the departments on the common issue.

Another interviewee supervisor stated;

Participation of teachers in decision making activities beyond their own class room was low. Because school leaders consider making decision and practicing each and every activity of the schools as his or her own responsibility and sometimes teachers in schools have no interest to participate in decision making activities. To me school leaders should open the boundaries to teachers and initiate them to participate in different schools activities. 
From the interview conducted with supervisors, the researcher summarized that, teachers' interest to participate in decision making activities was low. This is due to the absences of significant and well-built support among school leaders, absences of great concern for team work and creating sense of oneness among teachers in the schools under study area. This contradicts with the research by [17] stated, distributed leadership results are widely shared decision-making process viewed as the responsibilities of group rather than the individual.

\section{Extent of DL practices regarding its form of collective leadership}

For the respondents questionnaire which had five rating scale and stepwise regression analysis were discussed and the result was summarized in the following Table 5 and 6 .

Table-5: Distributive Leadership Practices in Relation to its Form of Collective Leadership

\begin{tabular}{|c|c|c|c|c|c|c|}
\hline \multirow[t]{2}{*}{ No } & \multirow[t]{2}{*}{ Items } & \multicolumn{2}{|c|}{$\begin{array}{l}\text { Teachers } \\
\mathrm{N}=120\end{array}$} & \multicolumn{2}{|c|}{$\begin{array}{l}\text { School lead } \\
\text { er } \\
\mathbf{N}=\mathbf{3 0}\end{array}$} & \multirow{2}{*}{$\begin{array}{l}\text { Total } \\
\mathrm{N}=15 \\
\mathbf{0} \\
\text { WM } \\
\end{array}$} \\
\hline & & $\mathbf{M}$ & $\mathbf{S D}_{1}$ & $\mathbf{M}$ & $\mathrm{SD}_{2}$ & \\
\hline 1 & $\begin{array}{l}\text { Teachers help one another in their respective school to practice } \\
\text { distributive leadership. }\end{array}$ & 2.50 & 0.68 & $\begin{array}{l}2.7 \\
0\end{array}$ & 0.59 & 2.54 \\
\hline 2 & $\begin{array}{l}\text { Teachers are provided with enough time to work together with } \\
\text { school leaders on the work related to their school. }\end{array}$ & 2.00 & 0.73 & $\begin{array}{l}2.5 \\
0\end{array}$ & 0.90 & 2.10 \\
\hline 3 & $\begin{array}{l}\text { Teachers in the school have common sense to exercises best } \\
\text { practices. }\end{array}$ & 2.08 & 0.68 & $\begin{array}{l}2.4 \\
0\end{array}$ & 0.93 & 2.14 \\
\hline
\end{tabular}

As per Table-5 item 1, indicated that, the mean scores (2.50 and 2.70) for teachers and school leaders were identified that there were at low and medium level regarding the issue of teachers help one another in their respective schools to practices distributive leadership. Generally, the weighted mean score (2.54) shows that there were at medium level regarding the issue of teachers help one another in their respective schools to practices distributive leadership. In relation to this, the standard deviation $\left(\mathrm{sd}_{1}=0.68\right.$ and $\left.\mathrm{sd}_{2}=0.59\right)$ for teachers and school leaders indicated that, there were little variability among respondents on the area of teachers help one another in their respective schools in relation to distributive leadership practices. From this one can conclude that, teachers in schools are help one another on the issues of practicing distributive leadership to some extent.

As expressed in the same Table-2 item 2, the mean score for teachers and school leaders were $(2.00$ and 2.50) with the weighted mean score of (2.10) were identified that there were at low level about the issues of teachers are provided with enough time to work together with school leaders on the work related to their schools. The standard deviation $\left(\mathrm{sd}_{1}=0.73\right.$ and $\mathrm{sd}_{2}=$ 0.90) for teachers and school leaders respondents also shows that there is a little variability among the respondents. From this one can understand that, teachers provided with enough time to work with school leaders were low.

As depicted in Table-5 item 3, the mean score for teachers and school leaders respondents were (2.08 and 2.40) were indicated there were at low level on the issues of teachers in the schools have common sense to exercises best practices. Generally, the weighted mean (2.14) indicated that there were at low level on the issues of teachers in the schools are common sense to exercises best practices. Besides to this, the standard deviation $\left(\mathrm{sd}_{1}=0.68\right.$ and $\left.\mathrm{sd}_{2}=0.93\right)$ for teachers and school leaders also shows that there were little variability among respondents on the issues of teachers in the school are a common sense to exercises distributive leadership best practices. From this one can understand that a teacher's common understanding to exercise distributive leadership best practices was low. In addition to the above descriptive analysis, the stepwise regression analysis was discussed as follows.

Table-6: Regression Analysis $(n i=150, P<0.05)$ on DL Practices Regarding its Form of Collective Leadership

\begin{tabular}{|c|c|c|c|c|c|}
\hline \multicolumn{6}{|l|}{ Coefficients } \\
\hline \multirow{3}{*}{$\begin{array}{l}\text { Model } \\
\text { 1. Constant }\end{array}$} & \multirow{3}{*}{$\begin{array}{l}\mathbf{R} \\
0.36\end{array}$} & \multirow{3}{*}{$\begin{array}{l}\mathbf{R}^{\mathbf{2}} \\
0.13\end{array}$} & \multicolumn{2}{|l|}{ USC } & \multirow{3}{*}{$\frac{\text { SC }}{\text { Beta }}$} \\
\hline & & & B & SE & \\
\hline & & & 1.29 & 0.19 & \\
\hline Teachers in the school have a common Sense to exercises best practices. & & & 0.38 & 0.08 & 0.36 \\
\hline
\end{tabular}

As per Table-6 reveals, the regression analysis on the extent of distributive leadership practices regarding its form of collective leadership in providing teachers common sense to exercises best practices in their respective schools measured by regression correlation coefficient (1.29) was contributing $13 \%$ to deteriorating to distributive leadership practices as measured by the stepwise regression analysis coefficient $\left(\mathrm{R}^{2}\right)^{*} 100$. The result means that $13 \%$ of the variation on the dependent variable is accounted for the 
variation in the independent variable whereas the rest unexplained variable $\left(1-\mathrm{R}^{2}\right) * 100$ were contributing $87 \%$ to deteriorating to distributive leadership practices. This means the rest of variation $87 \%$ is unexplained. The accompanying computer printout shows a regression equation that predicts on the areas teachers in the schools are a common sense to exercises best practices $\left(\mathrm{x}_{1}\right)$ that affect distributive leadership practices were expressed by statistically significant independent variables were $\mathrm{Y}=1.29+0.38 \mathrm{x}_{1}$ where 1.29 is constant. The positive slopes of a variable were 0.38 which used to indicate that as per a unit increase of the independent variable would tends to increase distributive leadership practices.

\section{Extent of DL practice in relation to recognizing other people's expertise}

For the respondents questionnaire which had five rating scale and stepwise regression analysis were discussed and the result was summarized in the following Table 7 and 8 .

Table-7: Distributive Leadership Practices in Relation to Recognizing other People Expertise

\begin{tabular}{|c|c|c|c|c|c|c|}
\hline \multirow[t]{2}{*}{ No } & \multirow[t]{2}{*}{ Items } & \multicolumn{2}{|c|}{$\begin{array}{l}\text { Teachers } \\
\mathbf{N}=120\end{array}$} & \multicolumn{2}{|c|}{$\begin{array}{l}\text { School le } \\
\text { ader } \\
\mathbf{N}=30\end{array}$} & \multirow{2}{*}{$\begin{array}{l}\text { Total } \\
\text { N=150 } \\
\text { WM }\end{array}$} \\
\hline & & $\mathbf{M}$ & $\mathbf{S D}_{1}$ & M & $\mathrm{SD}_{2}$ & \\
\hline 1 & $\begin{array}{l}\text { School leaders shares their experience to others to exercises best } \\
\text { practices. }\end{array}$ & 2.05 & 0.75 & $\begin{array}{l}3 . \\
16\end{array}$ & 0.83 & 2.27 \\
\hline 2 & $\begin{array}{l}\text { School leaders encourage teachers to engage } \\
\text { in professional development related to whole school issues (e.g. school } \\
\text { development planning, special needs, health and safety care etc). }\end{array}$ & 2.07 & 0.74 & $\begin{array}{l}3 . \\
00\end{array}$ & 0.78 & 2.25 \\
\hline 3 & $\begin{array}{l}\text { School leaders encourage teachers to participate in leading activities in } \\
\text { their school in addition to teaching and learning process. }\end{array}$ & 2.18 & 0.78 & $\begin{array}{l}3 . \\
06\end{array}$ & 0.94 & 2.35 \\
\hline 4 & $\begin{array}{l}\text { School leaders' review others polices and new ideas to practice } \\
\text { distributive leadership in their school. }\end{array}$ & 2.03 & 0.87 & $\begin{array}{l}2 . \\
90\end{array}$ & 0.80 & 2.20 \\
\hline
\end{tabular}

As indicated in Table-7 item 1, the mean score (2.05 and 3.16) for teachers and school leaders were identified that, there were at low and medium level on the issues of school leaders shares their experiences to others to exercise distributive leadership best practices. Generally, the weighted mean score (2.27) indicated that, there were low score on the issues of school leaders share his or her experiences has from others to exercise best practices. Besides to this, the standard deviation $\left(\mathrm{sd}_{1}=0.75\right.$ and $\left.\mathrm{sd}_{2}=0.83\right)$ for teachers and school leaders shows, there is little variability among respondents on the areas of school leaders share his or her experiences has from others to exercise best practices. From this one can concluded that, the extent that school leaders share his or her experiences has from others to exercise distributive leadership best practices was low.

As revealed in Table-7 item 2, the mean score (2.07 and 3.00) for teachers and school leaders indicated there were at low and medium level on the issues stated that, school leaders encourage teachers to engage in professional development related to the whole school issue like school development planning, special needs, health and safety care. Generally, the weighted mean score (2.25) indicated as low score regarding the issues of school leaders encourage teachers to engage in professional development related to the whole school issue like school development planning, special needs, health and safety care. Besides to this, the standard deviation $\left(\mathrm{sd}_{1}=0.74\right.$ and $\left.\mathrm{sd}_{2}=0.78\right)$ for teachers and school leaders shows there is a little variability among respondents on similar issues.
This implies that teacher encouragement in different activities like school development planning, special needs and others were low. In contradicts to this idea, Leithwood [9] determined that school leaders who actually uses the distributive leadership approach engage staff in behaviors such things as; setting the school direction, establishing professional development planning, redesigning the organization, and managing instruction.

With regard to Table-7 item 3, the mean score (2.18 and 3.06) for teachers and school leaders were indicated that there were at low and medium level on the idea of school leaders encourage teachers to participate in leading activities in their schools in addition to teaching learning process. Generally, the weighted mean score of the respondents were at low level. i.e., (2.35). In addition to this, the standard deviation $\left(\mathrm{sd}_{1}=0.78\right.$ and $\left.\mathrm{sd}_{2}=0.94\right)$ for teachers and school leaders indicates there were little variability among respondents on the issues of school leaders encourage teachers to participate in leading activities in their schools in addition to teaching learning process. From this one can realize that, the extent that school leaders encourage teachers to participate in leading activities in addition to teaching and learning process was low. In contradicts this idea, Visionary school leaders should encourage others to appeal to their higher and sometimes unrealistic ideals-translate their dreams into reality by articulating the vision, explaining the vision to others and developing the vision to others to achieve the desired goals [82]. 
According to Table-7 item 4, the mean score (2.03 and 2.90) for teachers and school leaders were indicated that there were at low and medium level regarding the idea stated that, school leaders review other practices, polices and generate new ideas to practices distributive leadership in their school. Generally, the weighted mean score of the respondents was (2.20) i.e., low score on similar issue. In addition, the standard deviation, $\left(\mathrm{sd}_{1}=0.87\right.$ and $\left.\mathrm{sd}_{2}=0.80\right)$ for teachers and school leaders also shows there were little variability among the respondents on the issues provided in the above table. From this one can understand that, the extent that school leader review other practices, polices and generate new ideas in order to practices distributive leadership under study area was low. In addition to the above descriptive analysis, the stepwise regression analysis was discussed as follows.

Table-8: Regression Analysis $(\mathrm{ni}=\mathbf{1 5 0}, \mathrm{P}<\mathbf{0 . 0 5})$ on DL Practices in Relation to Recognizing other People Expertise Coefficients

\begin{tabular}{|c|c|c|c|c|c|}
\hline \multirow[t]{3}{*}{ 1. Constant } & \multirow{3}{*}{$\begin{array}{l}\mathbf{R} \\
0 . \\
56\end{array}$} & \multirow{3}{*}{$\begin{array}{l}\mathbf{R}^{\mathbf{2}} \\
0 . \\
32\end{array}$} & \multicolumn{2}{|c|}{ USC } & \multirow{3}{*}{\begin{tabular}{|l|} 
S \\
C \\
$\mathrm{Be}$ \\
ta
\end{tabular}} \\
\hline & & & $\mathrm{B}$ & $\begin{array}{l}\mathrm{S} \\
\mathrm{E}\end{array}$ & \\
\hline & & & $\begin{array}{l}0 . \\
93\end{array}$ & $\begin{array}{l}0 . \\
17\end{array}$ & \\
\hline $\begin{array}{l}\text { School leaders encourage teachers to engage in professional development related to whol } \\
\text { e school issues (e.g. school development planning, special needs, health and safety care. }\end{array}$ & & & $\begin{array}{l}0 . \\
56 \\
\end{array}$ & $\begin{array}{l}0 . \\
07\end{array}$ & $\begin{array}{l}0 . \\
56\end{array}$ \\
\hline $\begin{array}{l}\text { School leaders encourage teachers to participate in leading activities in their school in } \\
\text { addition to teaching and learning process. }\end{array}$ & & & $\begin{array}{l}0 . \\
23\end{array}$ & $\begin{array}{l}0 . \\
07\end{array}$ & $\begin{array}{l}0 . \\
23\end{array}$ \\
\hline $\begin{array}{l}\text { School leaders' review others polices and new ideas to practice distributive leadership in } \\
\text { their school. }\end{array}$ & & & $\begin{array}{l}0 . \\
16\end{array}$ & $\begin{array}{l}0 . \\
07\end{array}$ & $\begin{array}{l}0 . \\
17\end{array}$ \\
\hline
\end{tabular}

As per Table- 8 reveals, the regression analysis on the extent of distributive leadership practices in relation to recognizing other people expertise measur ed by regression correlation coefficient (0.93) was contributing $32 \%$ to deteriorating the distrib utive leadership practices as measured by the stepwise regression analysis coefficient $\left(\mathrm{R}^{2}\right)^{*} 100$. The result means that $32 \%$ of the variation on the dependent variable is accounted for the variation in the independent variable whereas the rest unexplained variables $\left(1-\mathrm{R}^{2}\right) * 100$ were contributing $68 \%$ to deteriorating to distributive leadership practices. This means the rest of variation $68 \%$ is unexplained. The accompanying computer printout shows a regression equation that predicts School leaders encourage teachers to engage in professional development related to whole school issues (e.g. school development planning, special needs, health and safety care $\left(\mathrm{x}_{1}\right)$, school leaders encourage teachers to participate in leading activities in their schools in addition to teaching and learning process $\left(\mathrm{x}_{2}\right)$ and School leaders' review others polices and new ideas to practice distributive leadership in their $\operatorname{school}\left(\mathrm{x}_{3}\right)$ that affect distributive leadership practices were expressed by statistically significant independent vairab les were $\mathrm{Y}=0.93+0.56 \mathrm{x}_{1}+0.23 \mathrm{x}_{2}+0.16 \mathrm{x}_{3}$ where 0.93 is constant. The positive slopes of three variables respectively $0.56,0.23$ and 0.16 which used to indicate that as per a unit increase of the independent variables would tends to increases distributive leadership practices.

With regard to this an open ended question were asked both school leaders and teachers respondents how they participating in practicing distributive leadership in their school. All most all of the teachers and school leaders' response similar ideas but one of the teacher respondents stated that,

Distributive leadership is practiced by sharing of responsibility in managing student's behavior, class-room management, monitoring teachinglearning process, per-supervision and keeping school safety and etc. but there is no any participation regarding practices of distributive leadership in my school. In addition to this, both school leaders and teachers were unable to identify his or her area of participation regarding leadership practices.

The interview was conducted with schools supervisors that says is there any practice of distributive leadership in your schools so far? If yes, what it looks like? If no, what are the reasons for the absences? One of the interviewee supervisor response no answer, he said that,

The reason why $i$ answer no is, in my school there were no practices regarding the issue of leadership, its impotence's and how they practice. This is due to lack of awareness about the concepts of distributive leadership. However, some of the teachers were believed that practicing distributive leadership is only the role and responsibility of school leaders while the teachers' role is only class-room teaching.

Another interviewee supervisor also says that, one of the reasons why the distributive leadership is not practiced in my schools so far is: 
The school principal considered him or herself as the only actor of the schools to make important decision that affect the performance of school. Other supervisor also added that even if an attempt was made to empower stakeholders participating in schooling activities, still their role become minimal in making important decision that will improve learning outcome. Thus, still they are dominating with traditional leadership perspectives in which only those individuals formally appointed to leadership position empowered to leadership practices.

From the interview conducted with supervisors about the practices of distributive leadership, the researcher concluded that, some of the teachers in the sampled schools believe that, practicing distributive leadership is the role and responsibility of school leaders and school leaders are also unable to encourage teachers and recognize them in order to work with them collaboratively under study area. On contrary to this idea, Distributed leadership does not mean that no one besides the school leaders is responsible for the overall performance of the organization. All individuals are responsible and accountable for their contributions to the collective result [51].

\section{Perception of School Leaders and Teachers towards DL}

Teachers and school leaders were asked to rate the perception of distributive leadership practices. For the respondent's questionnaire which had five rating scale and stepwise regression analysis were dispatched and the result was summarized and to be discussed in details in the following Table 9 and 10.

Table-9: Responses of Respondents about the Perceptions of Distributive Leadership Practices

\begin{tabular}{|c|c|c|c|c|c|c|}
\hline \multirow[t]{2}{*}{ No } & \multirow[t]{2}{*}{ Items } & \multicolumn{2}{|c|}{$\begin{array}{l}\text { Teachers } \\
N=120\end{array}$} & \multicolumn{2}{|c|}{$\begin{array}{l}\text { School leader } \\
\mathbf{N}=30\end{array}$} & \multirow{2}{*}{$\begin{array}{l}\text { Total } \\
\text { N=15 } \\
\text { 0 } \\
\text { WM }\end{array}$} \\
\hline & & $\mathbf{M}$ & SD $_{1}$ & M & $\mathrm{SD}_{2}$ & \\
\hline 1 & $\begin{array}{l}\text { The school leader considers him or her self as knowledgeable } \\
\text { about distributive leadership practice }\end{array}$ & 3.83 & 1.23 & 2.03 & 0.96 & 3.47 \\
\hline 2 & $\begin{array}{l}\text { School leaders have knowledge about distributed leadership } \\
\text { concepts }\end{array}$ & 2.11 & 0.84 & 3.43 & 1.04 & 2.37 \\
\hline 3 & $\begin{array}{l}\text { School leaders and teachers } \\
\text { consider themselves as a decision maker in your school }\end{array}$ & 3.70 & 0.94 & 2.20 & 0.76 & 3.40 \\
\hline 4 & $\begin{array}{l}\text { School leaders and teachers are familiar with their colleagues } \\
\text { for taking leadership roles in the school. }\end{array}$ & 1.93 & 0.76 & 3.33 & 0.80 & 2.21 \\
\hline 5 & $\begin{array}{l}\text { School leaders are sharing their experiences with others in } \\
\text { schools }\end{array}$ & 1.93 & 0.90 & 3.13 & 0.86 & 2.17 \\
\hline
\end{tabular}

As expressed in Table-9 item 1, on the issues of the school leader considers him or herself as knowledgeable about distributive leadership practices, the mean score (3.83) for teachers and (2.03) for school leaders were identified that there were between agree and disagree score. Generally, the weighted mean score (3.47) were indicated undecided score regarding the issues of the school leader considers him or herself as knowledgeable about distributive leadership practices. The standard deviation $\left(\mathrm{sd}_{1}=1.23\right.$ and $\left.\mathrm{sd}_{2}=0.96\right)$ for teachers and school leaders expressed there were a little variability among respondents regarding the issues of the school leader considers him or herself as a knowledgeable about distributive leadership practices. From this one can conclude that respondents were not sure with knowledge that school leaders have in relation to distributive leadership practices under study area.

As indicated in Table-9 item 2, with regard to the issues of school leaders have knowledge about distributive leadership concepts, the mean score for teachers and school leaders were between disagree and undecided score i.e.(2.11 and 3.43) respectively. Generally, the weighted mean score (2.37) indicated that both teachers and school leaders respondents were disagree score on the area of school leaders have knowledge about distributive leadership concepts. The standard deviation $\left(\mathrm{sd}_{1}=0.84\right.$, and $\left.\mathrm{sd}_{2}=1.04\right)$ for teachers and school leaders also shows there were a little variability among respondents on the area of school leaders have knowledge about distributive leadership concepts.

As it can be seen from Table-9 item 3, the mean score (3.70 and 2.20) for teachers and school leaders were at agree and disagree score regarding the issues of school leaders and teachers consider themselves as a decision maker in their schools. Generally, the weighted mean score (3.40) identified that there were undecided score regarding the issues of the school leaders and teachers consider themselves as a decision maker in their school. In addition to this, the standard deviation $\left(\mathrm{sd}_{1}=0.94\right.$ and $\left.\mathrm{sd}_{2}=0.76\right)$ for teachers and school leaders also shows there is little variability among respondents on the area of school leaders and teachers are taken into consideration themselves as decision maker in their school.

As revealed in Table-9 item 4, regarding the issue of school leaders and teachers are familiar with 
their colleagues for taking leadership role in the school, the mean score for teachers and school leaders were (1.93 and 3.33) were felled under disagree and undecided score respectively. Generally, the weighted mean score (2.21) for teachers and school leaders were disagree score in the area of school leaders and teachers are familiar with their colleagues for taking leadership role in the school. In addition, The standard deviation $\left(\mathrm{sd}_{1}=0.76, \mathrm{sd}_{2}=0.80\right)$ for teachers and school leaders shows that, there were little variability among respondents regarding the issue of school leaders and teachers are familiar with their colleagues for taking leadership role in their school. From this one can conclude that, both teachers and school leaders were not familiar with their colleagues for taking leadership role with others in their school.
As reveled in Table-9 item 5, in the area of school leaders sharing their experiences with others in schools, the mean score (1.93) and (3.13) for teachers and school leaders were identified disagree and undecided score. Generally, the weighted mean score (2.17) indicated that both teachers and school leader respondents were at disagree score regarding the issues of school leaders sharing his or her experiences with others in school. In addition, the standard deviation $\left(\mathrm{sd}_{1}=0.90, \mathrm{sd}_{2}=0.86\right)$ for teachers and school leaders shows that, there is little variability among respondents regarding the issue of school leaders share his or her experiences with others in school. In addition to the abo ve descriptive analysis, the stepwise regression analysis was discussed as follows.

Table-10: Regression Analysis $(\mathrm{ni}=150, \mathrm{P}<0.05)$ Teachers and School Leaders Perception on DL practices

\begin{tabular}{|c|c|c|c|c|c|}
\hline \multicolumn{6}{|l|}{ Coefficients } \\
\hline \multirow{3}{*}{$\begin{array}{l}\text { Model } \\
\text { 1. Constant }\end{array}$} & $\mathbf{R}$ & $\mathbf{R}^{2}$ & \multicolumn{2}{|c|}{ USC } & $\mathbf{S}$ \\
\hline & \multirow[t]{2}{*}{$\begin{array}{l}0 . \\
52\end{array}$} & \multirow[t]{2}{*}{$\begin{array}{l}0 . \\
28\end{array}$} & B & $\begin{array}{l}\mathrm{S} \\
\mathrm{E}\end{array}$ & \multirow[t]{2}{*}{$\begin{array}{l}\mathrm{Be} \\
\mathrm{ta}\end{array}$} \\
\hline & & & $\begin{array}{l}2 . \\
47\end{array}$ & 0. & \\
\hline $\begin{array}{l}\text { School leaders encourage teachers to engage in professional development related to whole sc } \\
\text { hool issues (e.g. school development planning, special needs, health and safety care. }\end{array}$ & & & $\begin{array}{l}0 . \\
53\end{array}$ & $\begin{array}{l}0 . \\
09\end{array}$ & $\begin{array}{l}0 . \\
42\end{array}$ \\
\hline $\begin{array}{l}\text { School leaders encourage teachers to participate in leading activities in their school in } \\
\text { addition to teaching and learning process. }\end{array}$ & & & $\begin{array}{l}- \\
0 . \\
37\end{array}$ & $\begin{array}{l}0 . \\
10\end{array}$ & $\begin{array}{l}- \\
0 . \\
27\end{array}$ \\
\hline
\end{tabular}

As indicates in Table-10, the regression analysis in the area of teachers and school leaders perception on practicing distributive leadership measured by regression correlation coefficient (2.47) was contributing $28 \%$ to deteriorating distributive leadership practices as measured by the stepwise regression analysis correlation coefficient $\left(\mathrm{R}^{2}\right) * 100$. The result means that $28 \%$ of the variation on the dependent variable is accounted for the variation in the independent variable whereas the rest unexplained variables $\left(1-\mathrm{R}^{2}\right)^{*} 100$ were contributing $72 \%$ to deteriorating to distributive leadership practices. This means the rest of variation $72 \%$ is unexplained. The accompanying computer printout shows a regression equation that predicts school leaders and teachers are taken into consideration themselves as a decision maker in your school $\left(\mathrm{x}_{1}\right)$ and school leaders are sharing his or her experiences with others in $\operatorname{school}\left(\mathrm{x}_{2}\right)$ that affect the teachers and school leaders perception in practicing distributive leadership were expressed by statistically significant independent variables were $\mathrm{Y}=2.47+0.53 \mathrm{x}_{1}$ $0.37 x_{2}$ where 2.47 is constant. The positive slope of the first variables and the negative slope of the second variable respectively 0.53 and -0.37 are used to indicate that as per a unit increase of the first independent variable would tends to decrease and as per a unit decrease of the second variables would tends increases distributive leadership practices.
Similarly, in open ended question which says what is distributive leadership to you in your schools? How do you define? And what is the importance of practicing distributive leadership in your school?

One of the teacher respondents says that:

To me distributive leadership is sharing of the organizations responsibilities and decisions with the whole staffs willingly to achieve the common goal and its importance's is employee empowerment, sharing of responsibility, develop self-confidence, commitment and create awareness among schools staffs.

In relation to this, an interview was conducted with supervisors to supports the above findings, which says, what does distributive leadership mean for you? One of the interviewee supervisors uttered:

...to me distributive leadership is about sharing or distribution of activities or tasks among each other's equal to achieve common goal without discriminating others while task distribution.

Supporting to the above interview, Harris and Spillane [83] and Spillane [53] point out that leadership is no longer viewed solely on the principal's skill and 
knowledge, but it is viewed as the interactions between people and their situations.

\section{Major Challenges in Practicing Distributive Leadership}

Teachers and school leaders were asked to rate the major challenges in practicing distributive leadership. For the respondent's questionnaires which had five rating scale and stepwise regression analysis was dispatched and the result was summarized and to be discussed in details in the following table.

\section{Major challenges of distributive leadership practices related with school leaders}

For the respondents questionnaire which had five rating scale and stepwise regression analysis were discussed and the result was summarized in the following Table 11 and 12.

Table-11: Challenges in Practicing Distributive Leadership related with School Leaders

\begin{tabular}{|l|l|l|l|l|l|l|l|}
\hline No & Items & \multicolumn{2}{l|}{$\begin{array}{l}\text { Teachers } \\
\mathbf{N}=\mathbf{1 2 0}\end{array}$} & \multicolumn{2}{l|}{$\begin{array}{l}\text { School leader } \\
\mathbf{N}=\mathbf{3 0}\end{array}$} & $\begin{array}{l}\text { Total } \\
\mathbf{N}=150\end{array}$ \\
\cline { 3 - 7 } & & $\mathbf{M}$ & $\mathbf{S D}_{\mathbf{1}}$ & $\mathbf{M}$ & $\mathbf{S D}_{\mathbf{2}}$ & $\mathbf{W M}$ \\
\hline 1 & $\begin{array}{l}\text { School leaders feel that practicing } \\
\text { distributive leadership is the responsibility of principals not the } \\
\text { responsibility of teachers. }\end{array}$ & 3.59 & $\begin{array}{l}1.1 \\
5\end{array}$ & $\begin{array}{l}1.8 \\
6\end{array}$ & 0.93 & 3.24 \\
\hline 2 & $\begin{array}{l}\text { School leaders have knowledge on what kinds of tasks to be } \\
\text { distributed to teachers in their school }\end{array}$ & 2.10 & $\begin{array}{l}0.8 \\
2\end{array}$ & $\begin{array}{l}3.1 \\
0\end{array}$ & 0.80 & 2.30 \\
\hline 3 & $\begin{array}{l}\text { School leaders have the ability to influence teachers to follow the } \\
\text { desired direction }\end{array}$ & 2.15 & $\begin{array}{l}0.8 \\
2\end{array}$ & 3.1 & 1.13 & 2.34 \\
\hline
\end{tabular}

As revealed in Table-11 item 1, the mean score (3.59) and (1.86) for teachers and school leaders were identified that there were agree and disagree score on the issues of school leaders fell that practicing distributive leadership is the responsibility of principal rather responsibility of teachers. Generally, the weighted mean score (3.24) indicated that, both school leaders and teachers respondents were rate undecided score in the area of school leaders fell that practicing distributive leadership is the responsibility of principal rather responsibility of teachers. In addition, the standard deviation $\left(\mathrm{sd}_{1}=1.15\right.$ and $\left.\mathrm{sd}_{2}=0.93\right)$ for teachers and school leaders expressed that there were little variability among respondents regarding the area of practicing distributive leadership is responsibility of principals rather than the responsibility of teachers. This shows both school leaders and teachers respondents were not sure whether school leader fell practicing distributive leadership is the responsibility of principals or not. Supporting this idea, Torrance [60] performed that some of the challenges of distributed leadership in schools were, school leaders did not possess the talent and personality of teachers, Workloads of teachers and the issue of perception towards legitimate appointments confuses the issue of leadership among their colleagues.

In the above Table-11 item 2, it was analyzed response about the issues of school leaders have knowledge on what kinds of tasks to be distributed to teachers in their schools. Accordingly the mean score (2.10 and 3.10) for teachers and school leaders were rate disagree and undecided score with the weighted mean score of (2.30), i.e. disagree score on the issues of School leaders have knowledge on what kinds of tasks to be distributed to teachers in their school. In addition, the standard deviation $\left(\mathrm{sd}_{1}=0.82\right.$ and $\left.\mathrm{sd}_{2}=0.80\right)$ for teachers and school leaders also expresses, there were no variability among respondents on the issues of school leaders have knowledge on what kind of tasks to be distributed to teachers in their schools. This implies that, lack of ability to distribute tasks to teachers on the area of leadership activities was one of the challenges in practicing distributive leadership under study area.

As it can be seen from Table-11 item 3, the mean score (2.15 and 3.13) for teachers and school leaders were indicated disagree and undecided score about the areas of school leaders have ability to influence teachers to follow the desired direction. Generally, the weighted mean score (2.34) also shows there were disagree score among the respondents on the issues of school leaders have ability to influence teachers to follow the desired direction. Besides to this, the standard deviation $\left(\mathrm{sd}_{1}=0.82\right.$, and $\left.\mathrm{sd}_{2}=1.13\right)$ for teachers and school leaders shows there is little variability among respondents on similar issue. This indicates that lack of ability to influence teachers to follow the desired direction is one of the challenges in practicing distributive leadership. Supporting this ideas, Another significant challenges faced by school leaders while implementing distributive leadership is the difficulties in finding teachers that manage to implement the relevant tasks that were delegated. For example, a study by Abu [64] in Bangladesh reveals that school leaders encountering difficulties in delegating their tasks to the right teachers suitable for the job. In addition to the above descriptive analysis, the stepwise regression analysis was discussed as follows. 
Table-12: Regression Analysis $(\mathrm{ni}=150, \mathrm{P}<0.05)$ on the Major Challenges in Practicing DL related with school leaders Coefficients

\begin{tabular}{|c|c|c|c|c|c|}
\hline \multirow{3}{*}{$\begin{array}{l}\text { Model } \\
\text { 1. Constant }\end{array}$} & \multirow{3}{*}{$\frac{\mathbf{R}}{0.42}$} & \multirow{3}{*}{$\frac{\mathbf{R}^{2}}{0.17}$} & \multicolumn{2}{|l|}{ USC } & \multirow{3}{*}{$\begin{array}{l}\text { SC } \\
\text { Beta }\end{array}$} \\
\hline & & & B & SE & \\
\hline & & & 0.77 & 0.24 & \\
\hline $\begin{array}{l}\text { School leaders have knowledge on what kinds of tasks to be distributed to } \\
\text { teachers in their school }\end{array}$ & & & 0.38 & 0.08 & 0.35 \\
\hline $\begin{array}{l}\text { School leaders have the ability to influence teachers to follow the desired } \\
\text { direction }\end{array}$ & & & 0.22 & 0.08 & 0.21 \\
\hline
\end{tabular}

As Table-12 reveals, the regression analysis in the area of the major challenges in practicing distributive leadership related with school leaders measured by regression correlation coefficient $(0.77)$ was contributing $17 \%$ deteriorating to distributive leadership practices as measured by the stepwise regression analysis coefficient $\left(\mathrm{R}^{2}\right)^{*} 100$. The result means that $17 \%$ of the variation on the dependent variable is accounted for the variation in the independent variable whereas the rest unexplained variables $\left(1-R^{2}\right)^{*} 100$ were contributing $83 \%$ to deteriorating to distributive leadership practices. This means the rest of variation $83 \%$ is unexplained. The accompanying computer printout shows a regression equation that predicts school leaders have knowledge on what kinds of tasks to be distributed to teachers in their school $\left(\mathrm{x}_{1}\right)$ and school leaders have the ability to influence teachers to follow the desired direction $\left(\mathrm{x}_{2}\right)$ that affects distributive leadership practices were expressed by statistically significant independent variables were $\mathrm{Y}=0.77+0.38 \mathrm{x}_{1}+0.22 \mathrm{x}_{2}$ where 0.77 is constant. The positive slopes of two independent variables respectively were 0.38 and 0.22 which used to indicate that as per a unit increase of independent variables would tends to increase distributive leadership practices.

\section{Major challenges of distributive leadership practices related with teachers}

For the respondents questionnaire which had five rating scale and stepwise regression analysis were discussed and the result was summarized in the following Table-13 and 14.

Table-13: Challenges in Practicing Distributive Leadership related with Teachers

\begin{tabular}{|l|l|l|l|l|l|l|}
\hline No & Items & \multicolumn{2}{|l|}{$\begin{array}{l}\text { Teachers } \\
\mathbf{N = 1 2 0}\end{array}$} & \multicolumn{2}{l}{$\begin{array}{l}\text { School leader } \\
\mathbf{N}=\mathbf{3 0}\end{array}$} & $\begin{array}{l}\text { Total } \\
\mathbf{N}=\mathbf{1 5 0}\end{array}$ \\
\cline { 3 - 7 } & & $\mathbf{M}$ & $\mathbf{S D}_{\mathbf{1}}$ & $\mathbf{M}$ & $\mathbf{S D}_{\mathbf{2}}$ & $\mathbf{W M}^{\mathbf{W}}$ \\
\hline 1 & $\begin{array}{l}\text { Teachers have interest to participate in distributive leadership } \\
\text { activities in their school }\end{array}$ & 2.54 & 1.01 & 2.53 & 0.50 & 2.53 \\
\hline 2 & Teachers are willing to work in a team in their school & 2.51 & 0.92 & 2.50 & 0.68 & 2.50 \\
\hline 3 & There is shared responsibility among school teachers & 2.21 & 0.73 & 2.60 & 0.77 & 2.28 \\
\hline 4 & Teachers are willing to assume leadership role & 2.34 & 0.87 & 2.63 & 0.71 & 2.39 \\
\hline
\end{tabular}

As indicated in Table-13 item 1, the mean score for teachers and school leaders were $(2.54$ and 2.53) indicated that there were undecided score regarding the issue of teachers have interest to participate in distributive leadership activities in their school. Generally, the weighted mean scores (2.53) for both respondents reveals undecided score about the issue of teachers have interest to participate in distributive leadership activities in their school. The standard deviation $\left(\mathrm{sd}_{1}=1.01\right.$ and $\left.\mathrm{sd}_{2}=0.50\right)$ for teachers and school leaders indicated that, there is a variability among respondents in the area of teachers have interest to participate in distributive leadership activities. Therefore, one can understand that teachers in the schools may or may not have interest to participate in distributive leadership activities under study area.
As it can be seen from Table-13 item 2, the mean score for teachers and school leaders were $(2.51$ and 2.50) i.e. undecided and disagree score with the weighted mean score of (2.50) i.e. disagree score about the issue of teachers are willing to work in a team in their school. In addition to this, the standard deviation $\left(\mathrm{sd}_{1}=0.92\right.$ and $\left.\mathrm{sd}_{2}=0.68\right)$ for teachers and school leaders expresses there were a little variability among respondents regarding the issue of teachers are willing to work in a team in their schools. From this one can concluded that lack of team work among teachers in school were one of the major challenges that hinder the practices of distributive leadership under study area.

In the above Table-13 item 3 , it was analyzed the response about the issues of shared responsibility among school teachers. Accordingly, the mean scores (2.21 and 2.60) for teachers and school leaders were at disagree and undecided score. Generally, the weighted 
mean score (2.28) indicated that both teachers and school leaders were at disagree score in relation to the issues of shared responsibility among school teachers. The standard deviation of the item is also expresses $\left(\mathrm{sd}_{1}=0.73\right.$ and $\left.\mathrm{sd}_{2}=0.77\right)$ for teachers and school leaders were indicated that there were no variability among respondents. From this one can easily conclude that, lack of shared responsibility amongst teachers in schools was the major challenges that hinder the practice of distributed leadership under study area, because one of the major aspects of distributive leadership practice is shared responsibility.

As shown in Table-13 item 4, the mean score (2.34 and 2.63) for teachers and school leaders were indicated that, there were disagree and undecided score on the issues of teachers are willing to assume leadership role. Generally, the weighted mean score (2.39) indicated that both teachers and school leaders were at disagree score on the issues of teachers are willing to assume leadership role. In addition to this, the standard deviation $\left(\mathrm{sd}_{1}=0.87\right.$ and $\left.\mathrm{sd}_{2}=0.71\right)$ for teachers and school leaders also shows there is little variability among respondents. From this one can easily concludes, lack of willingness to assume leadership role amongst teachers in schools was the major challenges that hinder the practice of distributed leadership under study area. With regard to descriptive analysis, stepwise regression analysis was discussed as follows.

Table-14: Regression Analysis $(n i=150, P<0.05)$ on the Major Challenges in Practicing DL related with Teachers

\begin{tabular}{|c|c|c|c|c|c|}
\hline \multicolumn{6}{|l|}{ Coefficients } \\
\hline \multirow{3}{*}{$\begin{array}{l}\text { Model } \\
\text { 1. Constant }\end{array}$} & \multirow{3}{*}{$\begin{array}{l}\text { R } \\
0.46\end{array}$} & \multirow{3}{*}{$\begin{array}{l}\mathbf{R}^{2} \\
0.21\end{array}$} & \multicolumn{2}{|l|}{ USC } & \multirow{3}{*}{$\begin{array}{l}\text { SC } \\
\text { Beta }\end{array}$} \\
\hline & & & B & SE & \\
\hline & & & 1.31 & 0.21 & \\
\hline Teachers are willing to work in a team in their school & & & 0.49 & 0.08 & 0.46 \\
\hline
\end{tabular}

As indicated in Table-14, the regression analysis in the area of the major challenges in practicing distributive leadership related with teachers in providing teachers unwillingness to work in a team in their school measured by regression correlation coefficient (1.31) was contributing $21 \%$ to deteriorating distributive leadership practices as measured by the stepwise regression analysis coefficient $\left(\mathrm{R}^{2}\right) * 100$. The result means that $21 \%$ of the variation on the dependent variable is accounted for the variation in the independent variable whereas the rest unexplained variable $\left(1-\mathrm{R}^{2}\right)^{*} 100$ were contributing $79 \%$ to deteriorating to distributive leadership practices. This means the rest of variation $79 \%$ is unexplained. The accompanying computer printout shows a regression equation that predicts teachers willingness to work in a team in their $\operatorname{school}\left(\mathrm{x}_{1}\right)$ that affects distributive leadership practices were expressed by statistically significant independent variables were $\mathrm{Y}=1.31+0.49 \mathrm{x}_{1}$ where 1.31 is constant. The positive slope of a variable 0.49 which used to indicate that as per a unit increase of independent variable would tends to increase distributive leadership practices.

Major challenges of distributive leadership related to sc hool leaders and teachers

For the respondents questionnaire which had five rating scale and stepwise regression analysis were discussed and the result was summarized in the following Table 15 and 16.

Table-15: Challenges in Practicing Distributive Leadership related with School Leaders and Teachers

\begin{tabular}{|c|c|c|c|c|c|c|}
\hline \multirow[t]{2}{*}{ No } & \multirow{2}{*}{ | } & \multicolumn{2}{|c|}{$\begin{array}{l}\text { Teachers } \\
N=120\end{array}$} & \multicolumn{2}{|c|}{$\begin{array}{l}\text { School leader } \\
\mathbf{N}=30\end{array}$} & \multirow{2}{*}{$\begin{array}{l}\text { Total } \\
\text { N } \\
=150 \\
\text { WM } \\
\end{array}$} \\
\hline & & $\mathbf{M}$ & $\mathbf{S D}_{1}$ & $\mathbf{M}$ & $\mathbf{S D}_{2}$ & \\
\hline 1. & $\begin{array}{l}\text { There is collegial relationship between school leaders and teachers in } \\
\text { setting school direction }\end{array}$ & 2.01 & 0.76 & 2.96 & 0.92 & .20 \\
\hline 2. & There is smooth communication between school leader and teachers & 1.95 & 0.79 & 3.03 & 0.71 & 2.16 \\
\hline 3. & There is trust between teachers and school leaders in school & 1.80 & 0.70 & 2.96 & 0.88 & 2.03 \\
\hline
\end{tabular}

In the above Table-15 item 1, it was analyzed response about the issues of collegial relationship between school leaders and teachers in setting school direction. Accordingly, the mean score (2.01) for teachers and (2.96) for school leaders shows there were disagree and undecided score among the respondent. Generally, the weighted mean score (2.20) shows disagree score. In addition the standard deviation $\left(\mathrm{sd}_{1}=0.76\right.$ and $\left.\mathrm{sd}_{2}=0.92\right)$ for teachers and school leaders shows there was little variability among respondents on the issues of collegial relationship between school leaders and teachers in setting school direction. This indicates that, absences of collegial relationship among school leaders and teachers were one of the major challenges in practicing distributive leadership under study area.

As depicted in Table-15 item 2, the mean score (1.95) and (3.03) for teachers and school leaders shows there were disagree and undecided score in relation to 
the issues of there is smooth communication between school leaders and teachers. Generally, the weighted mean score (2.16) also shows there were disagree score regarding the issues of smooth communication between school leaders and teachers. The standard deviation $\left(\mathrm{sd}_{1}=0.79\right.$ and $\left.\mathrm{sd}_{2}=0.71\right)$ for teachers and school leaders reveals there were little variability among respondents on similar issue. This implies that, absences of smoothly communication between school leaders and teachers were one of the major challenges of distributive leadership practices under study area.

As the data shows in Table-15 item 3, the mean score for teachers and school leaders were (1.80 and 2.96), and this mean score were ranged at disagree and undecided score regarding the issues of there is trust between teachers and school leaders in school. Generally, the weighted mean score (2.03) indicated disagree score on the issues of there is trust between teachers and school leaders in school. In addition to this, the standard deviation $\left(\mathrm{sd}_{1}=0.70\right.$ and $\left.\mathrm{sd}_{2}=0.88\right)$ for teachers and school leaders shows there were little variability among respondents on the issues of there is trust between teachers and school leaders. From this one can realize that, lack of trust between teachers and school leaders were one of the major challenges of distributive leadership practices under study area. With regard to the above descriptive analysis, the stepwise regression analysis was discussed as follows.

\section{Table-16: Regression Analysis $(n i=150, P<0.05)$ on the Major Challenges in Practicing DL related with School Leaders and Teachers}

\begin{tabular}{|c|c|c|c|c|c|}
\hline \multicolumn{6}{|l|}{ Coefficients } \\
\hline \multirow{3}{*}{$\begin{array}{l}\text { Model } \\
\text { 1. Constant }\end{array}$} & \multirow{3}{*}{$\frac{\mathrm{R}}{0.47}$} & \multirow{3}{*}{$\begin{array}{l}\mathrm{R}^{2} \\
0.23\end{array}$} & \multicolumn{2}{|l|}{ USC } & \multirow{3}{*}{$\frac{\text { SC }}{\text { Beta }}$} \\
\hline & & & $\mathrm{B}$ & SE & \\
\hline & & & 0.99 & 0.18 & \\
\hline There is smooth communication between school leader and teachers & & & 0.34 & 0.08 & 0.35 \\
\hline There is trust between teachers and school leaders in school & & & 0.23 & 0.09 & 0.23 \\
\hline
\end{tabular}

As indicated in Table-16, the regression analysis in the area of the major challenges in practicing distributive leadership related with school leaders and teachers in providing there is smooth communication and trust between school leader $\mathrm{s}$ and teachers measured by regression correlation coeffi cient (0.99) was contributing $23 \%$ to deteriorating distri butive leadership practices as measured by the stepwise regression analysis coefficient $\left(\mathrm{R}^{2}\right)^{*} 100$. The result means that $23 \%$ of the variation on the dependent variable is accounted for the variation in the independent variable whereas the rest unexplained variable $\left(1-\mathrm{R}^{2}\right)^{*} 100$ were contributing $77 \%$ to deteriorating to distributive leadership practices. This means the rest of variation $77 \%$ is unexplained. The accompanying computer printout shows a regression equation that predicts there is smooth communication between school leader and teachers $\left(\mathrm{x}_{1}\right)$ and there is trust between teachers and school leaders in $\operatorname{school}\left(\mathrm{x}_{2}\right)$ that affects distributive leadership practices were expressed by statistically significant independent variables were $\mathrm{Y}=0.99+0.34 \mathrm{x}_{1}+0.23 \mathrm{x}_{2}$ where 0.99 is constant. The positive slopes of two independent variables respectively 0.34 and 0.23 which used to indicate that as per a unit increase of independent variables would tends to increase distributive leadership practices in schools.

The open ended question dispatched to teachers and school leaders to identify the challenges in practicing distributive leadership. The substance of their responses and comments were organized as follows. They said that, Some of the challenges of distributive leadership is reluctance of teachers to delegate, saying it is not concerned me, lack of finance, shortage of materials, fear of burden or work load, lack of ability and self-confidence, lack of experiences and deep understanding.

In addition, an interview was also conducted with supervisors, with regard to some of major challenges that they observed in their school during practicing distributive leadership.

One of the interviewee supervisor said that;

There are many challenges that hinder distributive leadership practices in my school, some of them are; lack of collaboration between teachers and school leaders in practicing best trends, absences of sharing each and every activities and work within, lack of commitment, lack of motivational skills and time were some of the major challenges.

Similar the other interviewee supervisor stated that; As I think distributive leadership is a new concepts which should be practiced in every organization, special in educational institutions, but there are many challenges that hinders the practices of distributive leadership, those are; absences of supportive school structure, lack of trust in working environment on behalf of stakeholders to address significant issue, lack of support from ZEO and WEO, lack of confidence as well as necessary awareness regarding the area of leadership practices were some of the major challenges. 
Supporting the above interview, Harris [15] suggested that structural, cultural and political challenges operating in the schools that make distributive form of leadership difficult to implement. In relation to this, Spillane and Danielson [5] also viewed that distributive leadership failed to practices in the schools due to time limitation on the parts of stakeholders.

\section{SUMMARY, CONCLUSIONS AND RECOMMENDATIONS}

This chapter deals with summary, conclusions and recommendations. In this section first, a summary of the study and the major findings were made. Second, depending on the findings conclusions were drawn. Lastly recommendations were made on the basis of the findings of the study.

\section{Summary}

The purpose of this study was to examine practices and challenges of distributive leadership in public secondary schools of East Hararghe Zone, Oromia Regional State and to come up with remedial solutions in order to bring the best practices. In order to solve these challenges, the following basic questions were raised in the study.

1. To what extent do secondary schools leaders and teachers participate in practicing distributive leadership in public secondary schools of EHZ?

2. How do teachers and school leaders perceive the concepts of distributive leadership under study area?

3. What are the major challenges in practicing distributive leadership under study area?

4. What are the possible strategies to be taken, in order to practices distributive leadership in secondary schools of EHZ?

In order to answer research question, related literature was reviewed. The study was carried out in 5 secondary schools of 4 Woredas and 1 secondary schools of 1 administrative town that were selected by simple random sampling techniques to the study from 58 secondary schools of 20 Woredas and 4 administrative town in East Hararghe Zone.

In this study descriptive survey research design with (quantitative and qualitative) approaches was employed. Data that are essential for the study was collected by using questionnaire and interview. The subject of the study were 6 schools principals, 6 viceprincipals, 12 unit leaders, 5 supervisors, 6 PTSA heads and 120 teachers. The researcher was used stratified random sampling technique to select teachers from each school and available sampling technique for selecting principals, vice principals, unit leaders, supervisors and PTSA heads. Both open ended and closed ended questionnaire was used for teachers respondents and school leaders (principals, vice principals, PTSA heads and unit leaders) while interview was used for supervisors.

In analyses of data, both quantitative and qualitative approaches were employed and the collected data were analyzed using SPSS software version 20 . Specifically, different statistical tools such as frequency, percentage, mean, standard deviation and weighted mean were used as descriptive statistical tools whereas, inferential statistics such as stepwise regression analysis were used to analyze the collected data. The analyses of the data secured from those instruments have revealed the following findings.

\section{Respondents Background}

The study showed that the numbers of male respondents were much greater than that of female respondents and the teaching-learning process, supervisor and leadership position were dominated by males in the secondary schools under the study. Regarding the ages of the respondents, the majority of them were between the age ranges of $25-30,30-35$ and $35-40$ as the study showed.

It was found from the response that, the majority of vice-principals, supervisors, unit leaders and teachers in the secondary schools was degree holders under study area. While some of the principals and all of the PTSA heads were master and diploma holders respectively. Regarding the respondents year of services, the majority of them were between the age range of 5-10 and 10-15.

\section{Extent of practicing distributive leadership}

The extent of practicing distributive leadership was seen from three angles, these were, extent in relation to its openness of the boundaries, form of collective leadership and recognize other people's expertise.

With respect to the area of practicing distributive leadership in relation to it is openness of the boundaries, most of the respondents shows their agreement as low score. i.e.1.73, 2.19 and 2.08 weighted mean score on the issues of practicing distributive leadership. Besides to this, the interview made with supervisors indicated that, teacher's participation in decision making activities beyond their own class-room was low. Because, school leaders consider making decision and practicing each and every activities of the school as his or her responsibility and sometimes teachers in schools have no interest to participate in decision making activities. They further indicated that school leaders should open the boundaries to teachers and initiate them to participate in different schools activities.

With regard to the area of practicing distributive leadership in relation to it is form of collective leadership, some of the respondent's shows 
their agreement low score. i.e. 2.10 and 2.14 weighted mean score and some of the respondents were shows their agreement as medium level. i.e. 2.54 weighted mean score.

Regarding the area of practicing distributive leadership in relation to recognizing other people expertise all most all respondents shows their agreement as low level score. i.e. 2.27, 2.25, 2.35 and 2.20 weighted mean score.

\section{Responses of respondents on the perceptions of distributive leadership}

With regard to the practices of distributive leadership in the area related with perception, some of the teachers and school leaders respondents indicated undecided score with the weighted mean score of (3.47 and 3.40) while most of the respondents identified disagree score with the weighted mean score of (2.37, 2.21 and 2.17) on the issues of teachers and school leaders perception towards distributive leadership practices.

\section{Challenges in practicing distributive leadership.}

The major challenges of distributive leadership practices was seen from three angels, these are challenges related with school leaders, teachers and both teachers and school leaders.

With regard to the major challenges of distributive leadership practices in relation to school leaders, most of the respondents showed that, school leaders and teachers found to be disagree score. i.e. 2.30 and 2.34 weighted mean score. While some of the respondents were indicated undecided score. i.e. 3.24.

With respect to the major challenges of distributive leadership practices in relation to teachers, most of the respondents depicted disagree scores. i.e., 2.50, 2.28 and 2.39 weighted mean score. This reveals that, unwillingness to work in team, lack of shared responsibility and lack of willingness to assume leadership role amongst teachers in schools were some of the challenges that hinder the practice of distributed leadership under study area.

Regarding challenges related with school leaders and teachers, most of the respondents reply disagree score. i.e., 2.20, 2.16 and 2.03 weighted mean score respectively. This indicates that absences of collegial relationship, lack of smoothly communication and trust between teachers and schools leaders were some of the major challenges of distributive leadership practices under study area.

\section{Possible strategies for the challenges of distributive leadership practices}

Regarding the possible strategies for the challenges of distributive leadership practices, the majority of respondents reveal that, creating favorable condition to create team leadership, sharing of knowledge and experiences, being accountable to once own task, maintaining atmosphere of trust and mutual respect, facilitate smooth communication and involving teachers in decision making activities, among school stakeholders were some of the possible strategies for the challenges in practicing distributive leadership.

\section{CONCLUSIONS}

Based on the summary of the major findings, the following major conclusions are derived in relation to basic question of the study.

The extent of practicing distributive leadership was seen from three angles, these were, extent in relation to its openness of the boundaries, form of collective leadership and recognize other people expertise that affect distributive leadership practices was measured by regression correlation coefficient was contributing $24 \%, 13 \%$ and $32 \%$ to deteriorating distributive leadership practices respectively and the rest of variables were unexplained variables. This needs more attention to scale up the areas of teachers participation, roles, willingness, common understanding and involvement in decision making activities in their respective schools in relation to distributive leadership best practices beyond their own class room.

Towards the perception of teachers and school leaders on distributive leadership practices, measured by regression correlation coefficient was contributing $28 \%$ to deteriorating distributive leadership practices and the rest of variables were unexplained variables. This needs more attention to solve the multi faced challenges as well as to realize the vision, and goals of the schools.

With regard to the major challenges of distributive leadership practices under study area, it was seen from three angels, these are challenges related with school leaders, teachers and both school leaders and teachers that affect distributive leadership practices measured by regression correlation coefficient was contributing $17 \%, 21 \%$ and $23 \%$ were deteriorating distributive leadership practices respectively, the rest of variables were unexplained variables. So, it was concluded that some of the challenges of distributive leadership practices were lack of knowledge on what kinds of tasks to be distributed to teachers, lack of interest to participate in practicing distributive leadership and Lack of collegial relationship among school leaders and teachers in setting school direction. Therefore, without addressing these challenges, it is so difficult to implement distributive leadership practices in schools.

Regarding the possible strategies to overcoming the challenges in practicing distributive leadership were measured by regression correlation was 
contributing $41 \%$ were deteriorating distributive leadership practices and the rest of variables were unexplained. From this one can conclude that, ensure well-built relation among school teachers and leaders, persuade team work, shared responsibility and creating favorable condition to facilitate team leadership in the school were some of the possible strategies in practicing distributive leadership. Therefore, a distributive leadership practice is effectively improved by applying the remedies forwarded by the respondents.

\section{RECOMMENDATIONS}

Based on the findings and conclusions of the study, the following recommendations were forwarded.

Zonal Education Office in collaboration with Woreda Education Beruea should Provide short and long term training to schools leaders and teachers regarding the area of leadership practices in the form of workshops and seminars, so as school leaders and teachers in schools become competent, skillful and knowledgeable about distributive leadership practices, how to practices and make the schools efficient and effective in achieving the objectives of the schools.

School leaders should establish collaborative relationship among school teachers in which they can share their experiences, ideas and learn from each other's concerning their profession to bring best practices of distributive leadership.

As shown in the finding of the study, teachers' involvement, willingness and chances to participate in decision in the areas of distributive leadership practices was low, so, school leaders should open the door to all teachers and work with them collaboratively to bring desired changes.

The study revealed that lack of team work, trust among school leaders and teachers, reluctance of teachers to delegate and habit of shared leadership is some of the major challenges in practicing distributive leadership. So, school leader in collaboration with zonal and woreda education Beruea should design possible strategies through preparing different training like; seminars and workshops for the implantations of effective distributive leadership.

It is known that, one of the challenges of schools is to implement the inclusive leadership practices approach. So as to enhance and foster sustainable leadership success, the researcher recommended that, playing the leadership role should not be tied to school leaders' position, but should be distributed among school teachers. Generally, in order to utilize teacher's unexploited potential, school leaders should view teachers as a partner in educational leadership process by stretching leadership roles across all teachers.
Finally, this study focused on limited variables in relation to practices and challenges of distributive leadership, so it recommended that future research investigation should focus on practicing distributive leadership challenges and its impacts on students' academic achievement.

\section{REFERENCES}

1. Gronn P. Distributed leadership as a unit of analysis. The Leadership Quarterly, 2002:13:423451.

2. Leithwood K, Mascall B, Strauss T, Sacks R, Memon N, Yashkina A. Distributing leadership to make schools smarter: taking the ego out of the system, Leadership and Policy in Schools, 2007:6(1):37-67.

3. Harris A. Distributed Leadership: Different Perspectives. Dordrecht: Springer. 2008.

4. Gronn P. Leadership: who needs it? School Leadership and Management, 2003:23(3):267-290.

5. Spillane JP, Camburn E. The practice of leading and managing: The distribution of responsibility for leadership and management in the schoolhouse. American Educational Research Association. 2006 Apr 7;22:1-38.

6. Spillane J, Diamond JB. Distributed Leadership in Practice. New York: Teachers College Press. 2007.

7. Deem R. Globalization New Managerilizim, Acad emic Capitalism, and Enterperiunalism in Universities, is the Local Dimension Still Important? Comparative Education, 2001:37(1):720.

8. Harris A, Lambert L. Building Leadership Capacity for School. Open University Press Maidenhead, Philadelphia, USA. 2003.

9. Leithwood K, Day C, Sammons P, Hopkins D, Harris A. Successful School Leadership: What it is and how it Influences Pupil Learning: Department of Education and Skills. Lunenburg. 2006.

10. Uhl-Bien M. Relational leadership theory: Exploring the social process of leadership and organizing. The leadership quarterly, 2006:17:654676.

11. Bennett N, Wise C, Woods P, Harvey JA. Distributed Leadership. Nottingham:

College of School Leadership. 2003.

12. Mayrowetz D. Making sense of distributed leadership: Exploring the multiple usages of the concept in the field. Educational Administration Quarterly, 2008:44(3):424-435.

13. Duignan P. Educational Leadership: Key Challenges and Ethical Tensions. New York: Cambridge University press. 2006.

14. Middlehurst R. Leading Academics. Buckingham: SRHE and OU Press. 1993.

15. Harris A. Distributed leadership: leading or misleading. Educational Management and Administration, 2004:32(1):11-24. 
16. Elmore R. Building a new structure for school leadership. American Educator, winter, 19992000:23(4):6-13.

17. Harris A, Muijs D. Improving schools through teacher leadership. UK: Open University Press. 2005.

18. Spillane JP. Educational leadership, Educational Evaluation and Policy Analysis, 2004:26(2):169172.

19. Hulpia H, Devos G. Development and validation of scores on the distributed leadership inventory. Educational and Psychological Measurement, 2009:20:1-22.

20. Leithwood K, Mascall B, Strauss T. New perspectives on an old idea: a short history of the old idea, in Leithwood K, Mascall B, Strauss T. (Eds), Distributed Leadership Routledge: London, 2009:1-14.

21. Misgana T. Principal distributive leadership practices in Hadiya Zone, in Southern Nations Nationalities and Peoples Regional State. 2017.

22. Dejane L. Practice and challenges of distributed leadership in Addis Abeba University. 2014.

23. Shimelis M. Practices and Challenges of Distributive Leadership Journal of Education and Practices, 2018:20(7).

24. Asrat D. The Practice and Challenges of Distributed Leadership. British Journal of Education, Society and Behavioral Science, 2017:20(3):1-10.

25. Gibb CA. Leadership GL. (Eds.). Handbook of Social Psychology, 2, 877-917. Reading, MA: Addison-Wesley. 1954.

26. Harris A, Leithwood K, Sammons P, Hopkins D. Distributed leadership and organizational change. Journal of Educational Change, 2007:8(4):337347.

27. Denis JL, Lamothe L, Langley A. The dynamics of collective leadership and Strategic change in pluralistic organizations. Academy of Management Journal, 2001:44(4):809-837.

28. Rosenthal CS. Determinants of collaborative leadership: civic engagement, gender or Organizational norms? Political

Research Quarterly, 1998:51(4):847- 868.

29. Henan D, Bennis W. Co-Leaders: The Power of Great Partnerships. Hoboken, NJ: Wiley. 1999.

30. Barker RA. The nature of leadership. Human Relations, 2001:54(4):469-494.

31. Harris A. Distributed Leadership: What we know'. In: Harris A. (Eds.) Distributed School Leadership: Different perspectives. London: Springer, 2009:11-21.

32. Gronn P. Distributed leadership. Second International Hand book of Educational Leadership and Administration. Leithwood K, Hallinger P. Dordrecht, Kluwer Academic Publishers, 2002:653-696.

33. Pearce CL,

The relative influence of vertical vs. shared leadership on

the longitudinal effectiveness of change managem ent teams. Group Dynamics: Theory, Research and Practice, 2002:6(2):172-197.

34. Pearce CL. The feature of leadership: combining vertical and shared leadership to transform knowledge work. Academic of management executive, 2004:18(1):47-57.

35. Day DV, Gronn P, Salas, E. Leadership capacity in terms. Leadership Quarterly, 2004:15:857-880.

36. Brown MH, Hosking DM. Distributed leadership and skilled performance as successful organization in social movements. Human Relations, 2004:39(1):65-79.

37. Hoy WK, Miskel GC. Educational Administration, Theory, Research and Practice ( $7^{\text {th }}$ Ed.). (Translation Editor: Selahattin Turan). Ankara: Nobel Publications. 2012.

38. Oduro GKT. Distributed leadership ${ }^{\text {ee }}$ in schools: what English head teachers say about the pull and push factors. Paper presented at the British Educational Research Association Annual Conference, University of Manchester. 2004.

39. Bostanc1 AB.

Turkish Adaptation of Shared Leadership Percepti on Scale. International Journal of Human Sciences, 2012:2(9):1619-1632.

40. Spillane JP, Halverson R, Diamond JB. Investigating school leadership practice: A distributed perspective. Educational Researcher, 2001:30:23-28.

41. Halverson R, Clifford M. Distributed instructional leadership in high schools. Journal of School Leadership. 2013 Mar;23(2):389-419.

42. Gronn P.

Distributed properties:A new architecture for leade rship. Education Management and Administration, 2000:28(3):371-388.

43. Macbeath J. Leadership as distributed: a matter of practice. School Leadership and management, 2005:25(4):349-366.

44. Silins H, Mulford W. Leadership and school results. In Leithwood $\mathrm{K}$, Hallinger P. (Eds), Second International Handbook of Educational Leadership and Administration. Dordrecht: Kluwer, 2002:561-612.

45. Yukl GA. Leadership in Organizations $\left(5^{\text {th }}\right.$ Ed.). New Jersey: Prentice-Hall. 2002.

46. Lambert L. Building Leadership Capacity in Schools. Alexandria, VA, USA ASCD. 1998.

47. Woods PA. Democratic leadership: drawing distinctions with distributed leadership, International Journal of Leadership in Education, 2004:7(1):3-26.

48. Timperley, H. S., 2005. Distributed leadership: developing theory from practice, Journal of Curriculum Studies, 37(4), 395-420.

49. Deal TE, Peterson KD. The Leadership Paradox. San Francisco, CA: Jossey- Bass. 1994. 
50. National College of School Leadership (NCSL). Distributed Leadership (Published Set of Booklets) Nottingham. 2004.

51. Elmore RF. School Reform from the Inside Out: Policy, Practice, and Performance. Cambridge, MA: Harvard Education Press. 2000.

52. Lambert L. Leadership capacity for lasting school improvement. ASCD; Alexandria, VA: Association for Supervision and Curriculum Development. 2003.

53. Spillane JP. Primary school leadership practice: How the subject matters. School leadership and management. 2005 Sep 1;25(4):383-97.

54. Watson ST, Scribner JP. Beyond distributed leadership: Collaboration, interaction, and emergent reciprocal influence. Journal of School Leadership. 2007 Jul;17(4):443-68.

55. Leithwood K, Mascall B, Strauss T, Sacks R, Memon N, Yaskina A. Distributing leadership to make schools smarter: Taking the ego out of the system. Leadership and Policy in Schools, 2006:6(1):37-67.

56. Moller J, Eggen AB. Team leadership in upper secondary education. School leadership and Management, 2005:25(4):331-347.

57. Simkins T. Leadership in Education: What works or what makes sense. Educational Management Administration and Leadership, 2005:33(1):9-26.

58. Timperley, H. Distributing leadership to improve outcomes for students, in Leithwood K, Mascall B, Strauss T. Distributed Leadership according to the Evidence, Routledge, London, 2009:197-222.

59. Bell, L. 2007. Perspectives on Educational manag ement and leadership, Continuum international publishing group, London.

60. Torrance D. Distributed leadership in Scottish primary schools: myth or actualities, unpublished doctor of Philosophy thesis, The Moray House School of Education, The University of Edinburgh. 2012.

61. Liljenberg M. Distributing leadership to establish developing and learning school organizations in the Swedish context". Educational Management Administration and Leadership, 2015:43(1):152170.

62. Fullan M. Change theory: A force for school improvement. Center for Strategic Education, 2006:157:3-14.

63. Fullan M, Scott G. Turn around Leadership for Higher Education. San Francisco: Jossey-Bass. 2009.

64. Abu N. Distributed Leadership in Secondary Schools: Possibilities and Impediments in Bangladesh. Arts Faculty Journal, 2011:19-32.

65. Kratzenmeyer M, Moller G. A wakening the sleeping giant: Helping teachers develop as leaders. Thousand Oaks, CA: Corwin Press. 2001.
66. Blase J. Empowering teachers: What successful Principal's do Thousand Oaks, CA: Corwin Press. 2001.

67. Kombo K, Tromp D. Proposal and thesis writing: An introduction. Nairobi: Publications of Africa. 2008.

68. Krebs CP, Lindquist CH, Warner TD, Fisher BS, Martin SL. The campus sexual assault (CSA) study. Washington, DC: National Institute of Justice, US Department of Justice. 2007 Dec.

69. Creswell JW, Plano Clark VL. Collecting data in mixed methods research. Designing and Conducting Mixed Methods Research. Thousand Oaks, CA: Sage Publications. 2011:171-202.

70. Creswell JW. Research design Qualitative, Quantitative and Mixed Method Appr oach Thousand Oaks, California: Sage publication. 2009.

71. Johnston A. Sampling hard-to-reach populations with respondent driven sampling: Methodological Innovations Online, 2010:5(2):38-48.

72. Ngwenya V. Managing parental involvement with education in Zimbabwe. PhD Dissertation Education Management, University of South Africa. 2010.

73. Kothari CR. Research Methodology, Methods and Techniques, Second Revised. 2004.

74. Yamane T. Statistics: An Introductory Analysis, $2^{\text {nd }}$ Ed., New York: Harper and Row. 1967.

75. Best JW, Kahn JV. Research in Education, $9^{\text {th }}$ Edition. Prentice-Hall of India Private Limited, New Delhi. 2003.

76. Kumer YS. Fundamental of Research Methodology and Statistics. Published by New Age International Ltd., Publishers. 2006.

77. Zikmund W, Babin B, Carr J, Griffin M. Business Research Methods. $8^{\text {th }}$ Edition. South western: Cengage Learning. 2010.

78. Pallant J. SPSS Survival Manual. $4^{\text {th }}$ Edition, Mcgraw Hill. 2010.

79. Gliem JA, Gliem RR. Calculating, interpreting, and reporting Cronbach's alpha reliability coefficient for Likert-type scales. Midwest Research-to-Practice Conference in Adult, Continuing, and Community Education. 2003.

80. Moe TM, Chubb JE. Liberating Learning: Technology, Politics, and the Future of American Education. John Wiley and Sons; 2009 Jul 15.

81. Lambert L. A framework for shared leadership. Educational leadership. 2002 May 1;59(8):37-40.

82. Ward K. A vision for tomorrow: transformational nursing leaders. Nursing Outlook. 2002 May 1;50(3):121-6.

83. Harris A, Spillane J. Management in education. British Educational Leadership, Management \& Administration Society (BELMAS) 